\title{
Uso popular de plantas medicinais e perfil socioeconômico dos usuários: um estudo em área urbana em Ouro Preto, MG, Brasil.
}

\author{
MESSIAS, M.C.T.B.,2;; MENEGATTO, M.F.3; PRADO, A.C.C.4; SANTOS B.R.4; GUIMARÃES, M.F.M. ${ }^{4}$ \\ 'Departamento de Biodiversidade, Evolução e Meio Ambiente, Universidade Federal de Ouro Preto (UFOP), \\ 35.400-000. Ouro Preto, MG, Brasil. 2Autor para correspondência: cristinabotanica@gmail.com ${ }^{3}$ Bacharel em \\ Farmácia / UFOP, Bolsista FAPEMIG, Estudante Mestrado Ecologia em Biomas Tropicais, UFOP.
}

\begin{abstract}
RESUMO: Este trabalho teve por objetivo identificar as plantas medicinais de uso popular e o perfil socioeconômico de seus usuários em área urbana de Ouro Preto, MG. O levantamento utilizou entrevistas semiestruturadas e amostragem aleatória, perfazendo $10 \%$ das residências. O grau de conhecimento sobre plantas medicinais foi medido pelo número de espécies citadas. Analisou-se a relação entre o saber popular sobre as plantas medicinais e características socioeconômicas dos entrevistados (renda, escolaridade, sexo, idade e forma de aquisição do conhecimento). Foram questionadas 6.713 pessoas, onde mais de $90 \%$ usam plantas medicinais para se tratarem. Identificou-se 342 espécies, reunidas em 94 famílias. Para cada espécie foram referidos os nomes populares, hábito, procedência, uso medicinal, parte usada, e forma de preparo. As principais moléstias tratadas com plantas foram: diarreia, insônia, gripe, hidropisia, distúrbios hepáticos, renais e do trato respiratório. Há um grande número de espécies nativas utilizadas. Dentre as exóticas, a maioria é de origem europeia. O uso místico de espécies, embora presente na cultura popular do município, foi pouco citado. Algumas espécies identificadas figuram na lista das espécies ameaçadas de extinção. O grau de conhecimento sobre plantas medicinais pela população de Ouro Preto independe, tanto do nível econômico, como da escolaridade ou do sexo. A idade e a forma de aquisição do conhecimento influenciam no saber popular das ervas medicinais. As pessoas com maior saber popular sobre as plantas adquiriram esses conhecimentos principalmente pelo costume familiar, por livros, ou por outras pessoas. Pessoas mais jovens conhecem menos espécies medicinais que as mais idosas, sugerindo risco de perda desse conhecimento tradicional. A grande riqueza de plantas citadas neste trabalho denota a importância de estudos etnobotânicos no resgate do conhecimento tradicional em áreas urbanas, tanto pelo seu valor histórico-cultural, como pela importância científica.
\end{abstract}

Palavras-chave:Conhecimento tradicional, etnobotânica, plantas medicinais, perfil socioeconômico, Ouro Preto - MG.

ABSTRACT: Popular use of medicinal plants and the socioeconomic profile of the users: a study in the urban area of Ouro Preto, Minas Gerais, Brazil. This work aimed to identify the medicinal plants of popular use and the socioeconomic profile of the users in the urban area of Ouro Preto, state of Minas Gerais, Brazil. The survey was carried out with random sampling and semi-structured interviews, amounting to $10 \%$ of households. The degree of knowledge about medicinal plants was measured by the number of species mentioned. The relationship between the popular knowledge about medicinal plants and the socioeconomic characteristics of the users (income, education, gender, age and type of knowledge acquisition) was also studied. In this survey, 6,713 inhabitants were questioned, of whom more than $90 \%$ use medicinal plants. A total of 342 species grouped in 94 families were identified. The popular names, growth habit, habitat, medicinal uses, part used and method of preparation are listed for each identified species. The main ailments treated with plants were diarrhea, insomnia, flu, dropsy and liver, renal and respiratory tract disorders. There is a large number of native species. Among the exotic ones, most are of European origin. The spiritual use of species, although present in the popular culture of the city, was negligible. Some species figure on the Brazilian red lists. It was noted that knowledge of medicinal plants by the population of Ouro Preto, in species richness, is not related to income, class, educational level and gender. The age and manner of acquisition

Rev. Bras. PI. Med., Campinas, v.17, n.1, p.76-104, 2015. 
of empirical knowledge about medicinal plants are associated with the number of species listed. Persons with greater popular knowledge about medicinal plants acquired information through family tradition, books and from other persons. Younger persons know fewer medicinal plants than the older ones, what suggests a loss of this traditional knowledge. The richness of the plants mentioned in this paper demonstrates the importance of ethnobotanical studies in the rescue of traditional knowledge in urban areas, for its scientific, historical and cultural values.

Key words: Ethnobotany, medicinal plants, Ouro Preto - MG - Brazil, socioeconomic profile, traditional knowledge.

\section{INTRODUÇÃO}

Plantas medicinais podem ser definidas como vegetais que possuem substâncias com ação terapêutica (Martins et al., 2003). O uso de plantas consideradas medicinais pela população é bastante difundido no Brasil e suas potencialidades neste setor são reconhecidas mundialmente (Simões et al., 2000). Estima-se que pelo menos a metade das espécies nativas possua alguma propriedade medicinal, entretanto nem $1 \%$ foi estudada adequadamente (Martins et al., 2003). Grande parte da população brasileira encontra nos produtos de origem natural, especialmente nas plantas medicinais, a única fonte de recursos terapêuticos. De acordo com Di Stasi (1996) isso se justifica tanto pela riqueza da biodiversidade, pela tradição popular desta prática, como também pelo baixo poder aquisitivo da população. No entanto, o grande impacto antrópico sobre os ecossistemas brasileiros tem levado à perda não só de biodiversidade, mas também da cultura e das tradições das comunidades que habitam estas áreas, que dependem de recursos do meio para sobreviver. Estes fatores demonstram a necessidade de incrementar os estudos etnobotânicos no Brasil (Diegues, 2000).

O conhecimento tradicional é de interesse para a ciência por se tratar de um acúmulo de saberes resultantes da observação sistemática de fenômenos biológicos feitos por pessoas, muitas delas analfabetas, mas tão perspicazes como o são alguns cientistas (Balick \& Cox, 1996). Como os conhecimentos tradicionais são transmitidos e mantidos principalmente pela oralidade, estudos etnobotânicos são importantes ferramentas para o seu resgate e registro, evitando-se assim que se percam ao longo do tempo. Informações adquiridas de comunidades que fazem uso da flora medicinal são utilizadas na formulação de hipóteses quanto às propriedades terapêuticas em estudos químicos e farmacológicos das espécies. Além disso, o conhecimento popular sobre o manejo da flora é útil na elaboração de estratégias conservacionistas com relação ao uso desses recursos (Albuquerque \& Hanazaki, 2006).

O município de Ouro Preto localiza-se entre os domínios da Mata Atlântica e Cerrado, com alta diversidade vegetal, em fitofisionomias campestres e florestais (Kamino et al., 2007). Esta circunstância somada à grande riqueza cultural de seus habitantes, com raízes europeias, africanas e indígenas, propicia uma vasta fonte de conhecimentos sobre a utilização de plantas. Este trabalho teve por objetivo identificar as plantas medicinais de uso popular e o perfil socioeconômico dos usuários em área urbana de Ouro Preto a fim de registrar as informações etnobotânicas do local, subsidiando políticas públicas voltadas à proteção e conservação ambiental e cultural da região.

\section{MATERIAL E MÉTODOS}

\section{Local de estudo}

Ouro Preto situa-se na região denominada Quadrilátero Ferrífero de Minas Gerais (Figura 1), a aproximadamente $20^{\circ} 30^{\prime}$ de latitude sul e $44^{\circ} 33^{\prime}$ de longitude oeste. O território de Ouro Preto corresponde a uma área de $1.274 \mathrm{~km}^{2}$, com 12 distritos (Amarantina, Antônio Pereira, Cachoeira do Campo, Engenheiro Correia, Glaura, Lavras Novas, Miguel Burnier, Rodrigo Silva, Santa Rita de Ouro Preto, Santo Antônio do Leite e Santo Antônio do Salto), além do distrito-sede com o centro da cidade e diversos bairros, com uma população de cerca de 66.000 habitantes (IBGE, 2010). A vegetação da região insere-se entre os domínios da Mata Atlântica e dos Cerrados (Rizzini, 1997), predominando os campos rupestres e as florestas estacionais. Seu relevo é acidentado, com altitude variando de 700 a $1.750 \mathrm{~m}$.

A geologia deste município, assim como do Quadrilátero Ferrífero, é bastante complexa. Há a ocorrência de rochas como gnaisses, filitos, xistos, quartzo-xistos, quartzitos, itabiritos, calcários, anfibolitos e esteáticos (Alkmin \& Marshak, 1998). O clima, de acordo com a classificação de Köppen é Cwb (tropical de altitude), ou seja, mesotérmico úmido, com a estação chuvosa de novembro a março e inverno seco (Nimer, 1989). A precipitação média anual é de $1250 \mathrm{~mm}$ e a temperatura média é de $20^{\circ} \mathrm{C}$. 


\section{Amostragem}

Foram feitas observações prévias do município utilizando-se mapas e levantamentos demográficos (IBGE, 2000), de modo a descrever a área e programar a amostragem a ser realizada.

Para os trabalhos etnobotânicos, a amostragem da população urbana da sede e dos 12 distritos foi sistemática, seguindo a metodologia proposta pelo IBGE (1983). Amostrou-se 10\% das residências de cada rua, em intervalos regulares, sorteando-se a residência inicial. Entrevistaram-se apenas os residentes presentes maiores de 18 anos e que residiam no local a pelo menos 10 anos.

\section{Coleta dos dados etnobotânicos}

Os dados etnobotânicos foram obtidos ao longo de 24 meses, nos anos de 1998 a 2000, através de entrevistas semiestruturadas com questões previamente definidas em um formulário (Tabela 1), mas permitindo ao informante responder segundo sua própria lógica e conceitos e acrescentar informações (Albuquerque et al., 2008). Pelas questões pré-definidas foram coletados dados socioeconômicos como: idade, sexo, nível de escolaridade, renda familiar e forma de aprendizado do uso de plantas medicinais. Para cada espécie vegetal citada foi registrado o nome popular, hábito, procedência, parte utilizada, forma de preparo, indicação e uso, número de coleta e características da planta necessárias para identificação e confecção da ficha da exsicata (cor, presença de látex, data e local da coleta, etc.). Posteriormente, procedeu- se a transcrição da linguagem popular para a científica, com respeito à forma de preparo e usos terapêuticos.

Todas as espécies citadas que se encontravam com partes reprodutivas foram coletadas, herborizadas, identificadas, classificadas de acordo com o APG III (2009) e depositadas no Herbário Professor Jose Badini (OUPR), da Universidade Federal de Ouro Preto. A nomenclatura científica foi aferida de acordo com os bancos de dados da Lista de Espécies da Flora do Brasil (2013) e The Plant List (2013).

\section{Análises dos resultados}

Calculou-se a riqueza (número) de espécies medicinais em cada família botânica.

Estimou-se o valor de uso das espécies medicinais pelos valores da frequência relativa (FR) de citação das mesmas (Magurran, 2004), pelas seguintes fórmulas:

$\mathrm{FR}_{\mathrm{i}}=\left(\mathrm{FA}_{\mathrm{i}} / \Sigma \mathrm{FA}\right) \times 100$

Onde: $F R_{i}=$ frequência relativa da espécie $\mathrm{i} ; \mathrm{FA}_{\mathrm{i}}=$ frequência absoluta da espécie i; $\Sigma F A=$ somatório das frequências absolutas das espécies.

Sendo: $F A_{i}=\left(n_{i} / N\right) \times 100$

Onde: $F A_{i}=$ frequência absoluta da espécie $\mathrm{i} ; \mathrm{n}_{\mathrm{i}}=$ número de pessoas que citaram a espécie $\mathrm{i}$; $\mathrm{N}=$ número total de entrevistados.

Para verificação dos efeitos dos dados socioeconômicos (sexo, idade, grau de escolaridade, renda mensal e forma de aquisição do conhecimento) sobre o grau de conhecimento de plantas medicinais

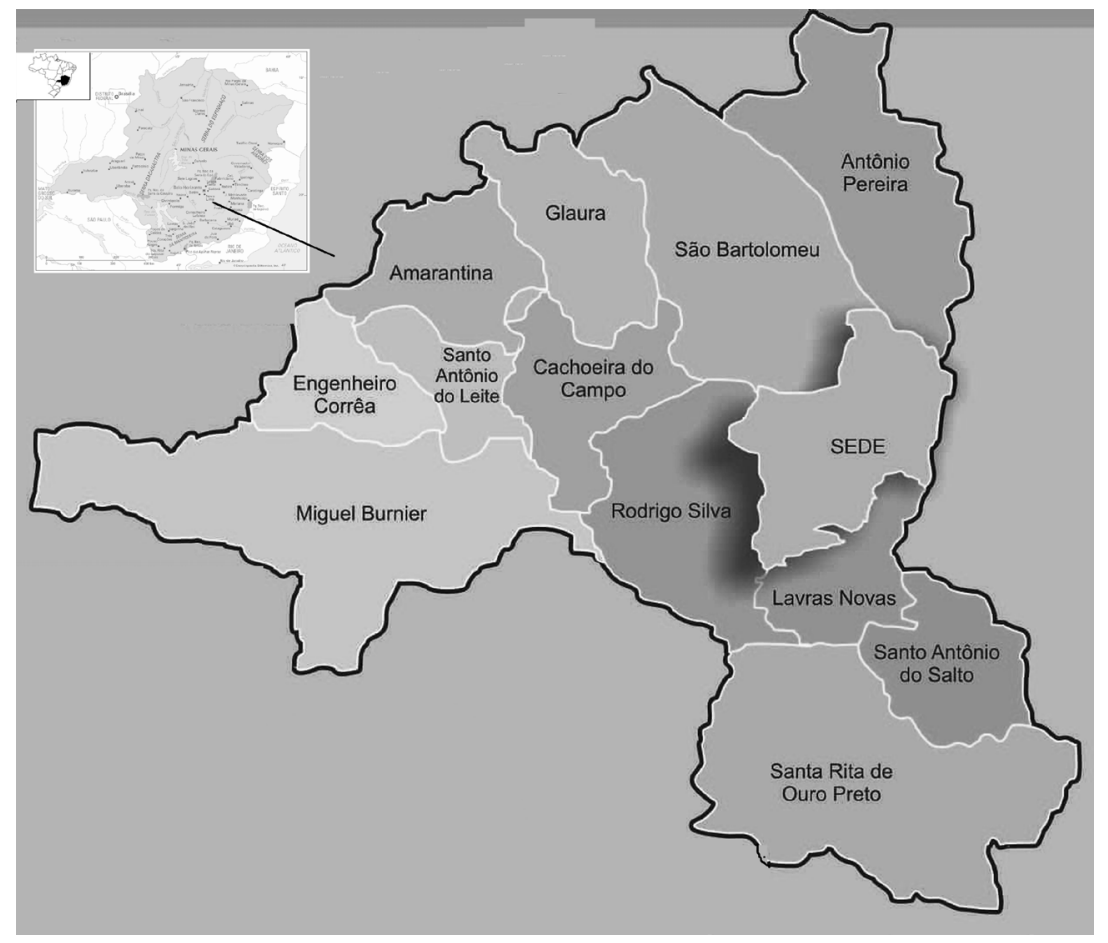

FIGURA 1. Localização da área de estudo e mapa do município de Ouro Preto, Minas Gerais, Brasil.

Rev. Bras. Pl. Med., Campinas, v.17, n.1, p.76-104, 2015. 
TABELA 1. Formulário utilizado em entrevistas para o levantamento de plantas medicinais utilizadas pela população urbana de Ouro Preto, MG, 1998-2000.
1. Nome:
2. Sexo:
3. Endereço:
4. Ocupação (qual sua atividade na comunidade, com o que trabalha):
5. Renda*
6. Escolaridade*
7. Idade*
*Investigar sem perguntar diretamente, se o entrevistado se sentir a vontade, ou deduzir pelas falas.
8. Conhece ou usa plantas medicinais?
9. Caso afirmativo, com quem aprendeu estes usos (familiares, amigos, livros, outros).
10. Averiguar se mais alguém da família aprendeu ou se interessa sobre o uso das plantas medicinais.
11. Listar as plantas medicinais conhecidas ou usadas anotando: nome popular, indicação de uso, parte usada, forma de preparo, forma de obtenção (procedência).
12. Perguntar se tem amostras da planta disponível para coleta. Perguntar também se tem disponibilidade para participar de uma turnê guiada nos locais de coleta.
13. Coletar as plantas, identificando-as com um número de coleta e anotar os dados importantes para a sua herborização e identificação (hábito de crescimento, habitat, coloração e outras características que se mostrarem importantes).
14.Perguntar ao entrevistado sobre a melhor forma de se apresentar os resultados da pesquisa que está sendo feita para a comunidade em que vive.

em termos de riqueza de espécies citadas foram realizadas análises de variância (ANOVA), usandose o Minitab (2008). Desde que verificado diferenças significativas, as médias foram testadas pelo teste de Tukey (Zar, 1999). Previamente à ANOVA, os dados foram testados para normalidade e homogeneidade de variâncias, pelos testes de Kolmogorov-Smirnov e Levene, respectivamente.

Em relação à idade, compuseram-se cinco classes etárias: menor de 20 anos, de 21 a 30 , de 31 a 40 , de 41 a 50 e acima de 50 anos. O grau de escolaridade foi dividido em sete classes: analfabeto, ensino fundamental incompleto, ensino fundamental completo, ensino médio incompleto, ensino médio completo, ensino superior incompleto e ensino superior completo. Quanto à renda, foram estabelecidas quatro classes: até 2 , de 2 a 5 , de 5 a 10 e acima de 10 salários mínimos.

\section{RESULTADOS E DISCUSSÃO}

Entrevistou-se 6.713 pessoas em 4.200 residências. Mais de $90 \%$ dos participantes da pesquisa usam plantas medicinais para se tratarem.

Foram identificadas 342 espécies, reunidas em 260 gêneros e 94 famílias, cujos nomes populares, usos medicinais, parte usada, forma de preparo, hábito de crescimento e procedência estão apresentados na Tabela 2.
Grande parte das espécies medicinais citadas são cultivadas (46,8\%), $20 \%$ são extraídas de campos rupestres, $19 \%$ de florestas, $13,2 \%$ são ruderais e menos de 1\% são oriundas de locais brejosos (Tabela 2). A metade das espécies citadas são ervas, seguidas pelos arbustos (20\%), árvores $(11 \%)$, subarbustos e lianas ( $9 \%$ cada) e parasitas (1\%). As folhas são as partes mais utilizadas nos preparos e as sementes, as menos usadas (Tabela 2) A predominância de ervas pode estar relacionada ao fato de que a maioria delas são passíveis de cultivo nos quintais, ou serem ruderais, facilitando a obtenção desses recursos vegetais (Pilla et al., 2006). O uso mais expressivo de folhas representa uma boa pratica de manejo sustentável da flora, provocando menores impactos sobre as populações das espécies utilizadas. O uso preferencial de folhas também foi verificado em outros trabalhos de natureza semelhante (Pilla et al., 2006; Hanazaki et al., 2000)

As famílias com maior número de espécies citadas foram: Asteraceae, Lamiaceae, Fabaceae, Amaranthaceae, Solanaceae, Poaceae, Rubiaceae, Apiaceae, Euphorbiaceae, Myrtaceae, Cucurbitaceae, Rosaceae, Rutaceae, Malvaceae e Verbenaceae (Figura 2). Asteraceae e Lamiaceae tem sido citadas como famílias com maior riqueza de espécies medicinais em diversos levantamentos de espécies medicinais (Pilla et al., 2006; Hanazaki et al., 2000) 
TABELA 2. Espécies identificadas como medicinais em levantamento etnobotânico em área urbana no município de Ouro Preto, Minas Gerais, Brasil, 1998-2000. (V = voucher, número de registro no Herbário OUPR, NC = não coletado)

\begin{tabular}{|c|c|c|c|c|c|c|c|}
\hline Família / Espécie & Nome popular & Parte usada & Preparo & Indicação & Hábito & Procedência & $\mathbf{v}$ \\
\hline \multicolumn{8}{|l|}{ Adoxaceae } \\
\hline $\begin{array}{l}\text { Sambucus australis } \\
\text { Cham. \& Schltdl. }\end{array}$ & sabugueiro & Inflorescência & Infuso & $\begin{array}{l}\text { Antigripal, contra sarampo e } \\
\text { catapora }\end{array}$ & Arbusto & Cultivado & 23244 \\
\hline \multicolumn{8}{|l|}{ Aizoaceae } \\
\hline $\begin{array}{l}\text { Tetragonia tetragonoides } \\
\text { (Pall.) Kuntze }\end{array}$ & espinafre & Folha & Refogado & Para afecções intestinais & Erva & Cultivado & 2282 \\
\hline \multicolumn{8}{|l|}{ Alismataceae } \\
\hline $\begin{array}{l}\text { Echinodorus macrophyllus } \\
\text { (Kunth) Micheli }\end{array}$ & chapéu-de-couro & Folha & $\begin{array}{l}\text { Decocto ou } \\
\text { infuso }\end{array}$ & $\begin{array}{l}\text { Depurativo do sangue, para } \\
\text { afecções renais e urinárias, } \\
\text { antialérgico, anti-inflamatório }\end{array}$ & Erva & $\begin{array}{l}\text { Campo } \\
\text { brejoso }\end{array}$ & 6714 \\
\hline \multicolumn{8}{|l|}{ Alstroemeriaceae } \\
\hline $\begin{array}{l}\text { Bomarea edulis (Tussac) } \\
\text { Herb. }\end{array}$ & cará-de-caboclo & Raiz & Decocto & Diaforético e diurético & Liana & Floresta & 1309 \\
\hline \multicolumn{8}{|l|}{ Amaranthaceae } \\
\hline $\begin{array}{l}\text { Alternanthera brasiliana } \\
\text { (L.) Kuntze }\end{array}$ & perpétua-branca & Folha & Decocto & Anti-inflamatório uterino. & Erva & Ruderal & 5857 \\
\hline $\begin{array}{l}\text { Alternanthera } \\
\text { philoxeroides (Mart.) } \\
\text { Griseb. }\end{array}$ & dipirona, novalgina & Folha & Infuso & Antipirético, analgésico & Erva & Cultivado & 12678 \\
\hline Alternanthera sp.1 & perpétua, anador & Flor & Infuso & $\begin{array}{l}\text { Para afecções respiratórias } \\
\text { e ginecológicas, anti- } \\
\text { inflamatório }\end{array}$ & Erva & Ruderal & 22403 \\
\hline Alternanthera sp.2 & $\begin{array}{c}\text { penicilina, } \\
\text { antibiótico, } \\
\text { perpétua-branca }\end{array}$ & Folha & Infuso & Anti-inflamatório, antibiótico & Erva & Ruderal & 5050 \\
\hline Amaranthus spinosus L. & carurú & Folha & Refogado & $\begin{array}{l}\text { Para desnutrição infantil, } \\
\text { remineralizante, laxante }\end{array}$ & Erva & Ruderal & 1561 \\
\hline Beta vulgaris L. & beterraba & Raiz & \begin{tabular}{|l} 
Ingestão crua ou \\
cozida
\end{tabular} & Aperiente, antianêmico & Erva & Cultivado & 26469 \\
\hline $\begin{array}{l}\text { Beta vulgaris subsp. cicla } \\
\text { (L.) Alef. }\end{array}$ & acelga & Folha & Suco & Contra cálculos biliares & Erva & Cultivado & NC \\
\hline $\begin{array}{l}\text { Chenopodium } \\
\text { ambrosioides } \mathrm{L} .\end{array}$ & $\begin{array}{l}\text { mastruz, erva-de- } \\
\text { santa maria, santa- } \\
\text { maria }\end{array}$ & Folha & $\begin{array}{l}\text { Macerado, } \\
\text { decocto ou } \\
\text { infuso }\end{array}$ & $\begin{array}{l}\text { Vermífugo, para problemas } \\
\text { da adenoide e sinusite, } \\
\text { antigripal, anti-inflamatório, } \\
\text { contra cálculos renais, } \\
\text { antidiarréico }\end{array}$ & Erva & Ruderal & 13407 \\
\hline $\begin{array}{l}\text { Gomphrena arborescens } \\
\text { L.f. }\end{array}$ & paratudo & Folha e caule & Infuso & $\begin{array}{l}\text { Anti-inflamatório, antibiótico, } \\
\text { antigripal, para afecções } \\
\text { da pele }\end{array}$ & Erva & Cultivado & 7673 \\
\hline $\begin{array}{l}\text { Gomphrena scapigera } \\
\text { Mart. }\end{array}$ & dipirona, novalgina & Folha & Infuso & Antipirético & Erva & $\begin{array}{l}\text { Campo } \\
\text { rupestre }\end{array}$ & 5711 \\
\hline Gomphrena sp. & penicilina & Folha & Infuso & Antibiótico & Erva & Ruderal & 7460 \\
\hline $\begin{array}{l}\text { Pfaffia glomerata } \\
\text { (Spreng.) Pedersen }\end{array}$ & $\begin{array}{l}\text { penicilina, } \\
\text { terramicina }\end{array}$ & Folha & Infuso & $\begin{array}{l}\text { Antibiótico para eczemas e } \\
\text { infecções em geral }\end{array}$ & Erva & Ruderal & 7739 \\
\hline $\begin{array}{l}\text { Pfaffia gnaphaloides (L.f.) } \\
\text { Mart. }\end{array}$ & $\begin{array}{c}\text { terramicina, } \\
\text { perpétua-branca }\end{array}$ & Folha & Infuso & Expectorante, antipirético & Erva & $\begin{array}{l}\text { Campo } \\
\text { rupestre }\end{array}$ & 4002 \\
\hline \multicolumn{8}{|l|}{ Amaryllidaceae } \\
\hline Allium cepa L. & cebola-de-cabeça & Caule & Decocto & $\begin{array}{l}\text { Antigripal, béquico, } \\
\text { expectorante, } \\
\text { para bronquites, } \\
\text { hipocolesterolêmico }\end{array}$ & Erva & Cultivado & 17723 \\
\hline Allium fistulosum $\mathrm{L}$. & cebolinha & Folha e caule & $\begin{array}{l}\text { Decocto, } \\
\text { macerado com } \\
\text { mel }\end{array}$ & $\begin{array}{l}\text { Antigripal, béquico, } \\
\text { expectorante, }\end{array}$ & Erva & Cultivado & 13694 \\
\hline Allium sativum $\mathrm{L}$. & alho & Caule & $\begin{array}{l}\text { Decocto ou } \\
\text { macerado em } \\
\text { óleo }\end{array}$ & $\begin{array}{l}\text { Antigripal, béquico, } \\
\text { expectorante }\end{array}$ & Erva & Cultivado & NC \\
\hline \multicolumn{8}{|l|}{ Anacardiaceae } \\
\hline $\begin{array}{l}\text { Anacardium humile A.St.- } \\
\text { Hil. }\end{array}$ & caju-do-campo & $\begin{array}{c}\text { Folha e casca } \\
\text { do caule }\end{array}$ & Decocto & $\begin{array}{l}\text { Cicatrizante e } \\
\text { hipoglicemiante }\end{array}$ & Arbusto & $\begin{array}{l}\text { Campo } \\
\text { rupestre }\end{array}$ & 26481 \\
\hline
\end{tabular}


TABELA 2. Espécies identificadas como medicinais em levantamento etnobotânico em área urbana no município de Ouro Preto, Minas Gerais, Brasil, 1998-2000. ( V = voucher, número de registro no Herbário OUPR, NC = não coletado)

\begin{tabular}{|c|c|c|c|c|c|c|c|}
\hline $\begin{array}{l}\text { Lithraea molleoides (Vell.) } \\
\text { Engl. }\end{array}$ & aroeirão & Casca do caule & Decocto & Anti-inflamatório & Árvore & Floresta & 8780 \\
\hline Mangifera indica L. & manga & Folha & $\begin{array}{l}\text { Decocto ou } \\
\text { infuso }\end{array}$ & Béquico & Árvore & Cultivado & 179 \\
\hline $\begin{array}{l}\text { Schinus terebinthifolius } \\
\text { Raddi }\end{array}$ & aroeira & $\begin{array}{l}\text { Casca do caule, } \\
\text { folha e fruto }\end{array}$ & Decocto & $\begin{array}{l}\text { Anti-inflamatório, contra } \\
\text { afecções das vias } \\
\text { respiratórias e urinárias }\end{array}$ & Arbusto & Floresta & 6175 \\
\hline \multicolumn{8}{|l|}{ Annonaceae } \\
\hline Annona reticulata $\mathrm{L}$. & graviola & Folha & Decocto & $\begin{array}{l}\text { Vermífugo (contra } \\
\text { esquistossomose) }\end{array}$ & Árvore & Cultivado & 26483 \\
\hline $\begin{array}{l}\text { Guatteria villosissima } \\
\text { A.St.-Hil. }\end{array}$ & pindaíba, embira & Fruto & Decocto & Carminativo & Árvore & Floresta & 8784 \\
\hline $\begin{array}{l}\text { Xylopia brasiliensis } \\
\text { Spreng. }\end{array}$ & $\begin{array}{l}\text { pindaíba, pimenta- } \\
\text { de-macaco, embira }\end{array}$ & Fruto & Decocto & Carminativo & Árvore & Floresta & 1398 \\
\hline \multicolumn{8}{|l|}{ Apiaceae } \\
\hline Apium graveolens $\mathrm{L}$. & aipo, salsão & Folha & $\begin{array}{l}\text { Decocto ou } \\
\text { infuso }\end{array}$ & $\begin{array}{l}\text { Laxante, para afecções } \\
\text { da boca e garganta, } \\
\text { carminativo, eupéptico, para } \\
\text { insuficiência respiratória e } \\
\text { contra cólicas menstruais. }\end{array}$ & Erva & Cultivado & 8708 \\
\hline $\begin{array}{l}\text { Apium leptophyllum } \\
\text { (Pers.) F. Muell. ex Benth. }\end{array}$ & funcho & Parte aérea & Infuso & Calmante, hipotensor & Erva & Cultivado & 8662 \\
\hline $\begin{array}{l}\text { Apium prostratum Labill. } \\
\text { Eex Vent. }\end{array}$ & $\begin{array}{l}\text { agrião, agrião-da- } \\
\text { folha-grande }\end{array}$ & Folha & $\begin{array}{l}\text { Xarope, in } \\
\text { natura }\end{array}$ & $\begin{array}{l}\text { Béquico, expectorante e } \\
\text { antigripal }\end{array}$ & Erva & Cultivado & 7450 \\
\hline Centella asiatica (L.) Urb. & $\begin{array}{l}\text { centela-asiática, } \\
\text { erva-capitão }\end{array}$ & Planta toda & $\begin{array}{l}\text { Macerado em } \\
\text { álcool }\end{array}$ & Aperiente, depurativo & Erva & Ruderal & 6381 \\
\hline Coriandrum sativum $\mathrm{L}$. & coentro & Folha & $\begin{array}{l}\text { Como } \\
\text { condimento }\end{array}$ & Eupéptico & Erva & Cultivado & 7706 \\
\hline $\begin{array}{l}\text { Eryngium paniculatum } \\
\text { Cav. \& Dombey ex } \\
\text { F.Delaroche }\end{array}$ & língua-de-tucano & Folha & Decocto & Diurético & Erva & $\begin{array}{l}\text { Campo } \\
\text { rupestre }\end{array}$ & 1352 \\
\hline \multirow[t]{2}{*}{ Foeniculum vulgare Mill. } & erva-doce, funcho & Fruto & $\begin{array}{l}\text { Decocto ou } \\
\text { infuso }\end{array}$ & $\begin{array}{l}\text { Calmante, antidiarréico, } \\
\text { antigripal, cólicas intestinais } \\
\text { de recém-nascido, } \\
\text { galactagogo }\end{array}$ & Erva & Cultivado & 7446 \\
\hline & & Folha & Decocto & $\begin{array}{l}\text { Calmante, antidiarréico, } \\
\text { béquico, carminativo, } \\
\text { eupéptico, antigripal, } \\
\text { para afecções cardíacas, } \\
\text { hipotensor, para bronquite, } \\
\text { cólicas intestinais de recém- } \\
\text { nascidos e angina }\end{array}$ & & & 7446 \\
\hline \multirow[t]{2}{*}{$\begin{array}{l}\text { Petroselinum crispum } \\
\text { (Mill.) Fuss }\end{array}$} & salsa & Folha & $\begin{array}{l}\text { Como } \\
\text { condimento }\end{array}$ & Antianêmico, eupéptico & Erva & Cultivado & 4669 \\
\hline & & Raiz & Decocto & $\begin{array}{l}\text { Anti-inflamatório, para } \\
\text { infecções urinárias e } \\
\text { ginecológicas, anti- } \\
\text { inflamatório, analgésico } \\
\text { para cólicas menstruais, } \\
\text { estomáquico e calmante }\end{array}$ & & & 4669 \\
\hline Pimpinela anisum L. & erva-doce & Folha e fruto & $\begin{array}{l}\text { Infuso ou } \\
\text { decocto }\end{array}$ & $\begin{array}{l}\text { Calmante, eupéptico, } \\
\text { estomáquico e antigripal. }\end{array}$ & Erva & Cultivado & 7753 \\
\hline \multicolumn{8}{|l|}{ Apocynaceae } \\
\hline \multirow[t]{2}{*}{$\begin{array}{l}\text { Mandevilla velame (A.St.- } \\
\text { Hil.) Pichon }\end{array}$} & $\begin{array}{c}\text { velame, velame-do- } \\
\text { campo }\end{array}$ & Folha e raiz & Decocto & Antibiótico, antissifilítico & Erva & $\begin{array}{l}\text { Campo } \\
\text { rupestre }\end{array}$ & 357 \\
\hline & & Raiz & $\begin{array}{l}\text { Macerado em } \\
\text { vinho branco }\end{array}$ & $\begin{array}{l}\text { Antirreumático, depurativo, } \\
\text { tônico }\end{array}$ & & & \\
\hline \multicolumn{8}{|l|}{ Aquifoliaceae } \\
\hline Ilex conocarpa Reissek & congonha-do-gentio & Folha & Decocto & Diurético, calmante & Arbusto & $\begin{array}{l}\text { Campo } \\
\text { rupestre e } \\
\text { floresta }\end{array}$ & 13606 \\
\hline
\end{tabular}


TABELA 2. Espécies identificadas como medicinais em levantamento etnobotânico em área urbana no município de Ouro Preto, Minas Gerais, Brasil, 1998-2000. (V = voucher, número de registro no Herbário OUPR, NC = não coletado)

\begin{tabular}{|c|c|c|c|c|c|c|c|}
\hline $\begin{array}{l}\text { Ilex loranthoides Mart. ex } \\
\text { Reissek }\end{array}$ & $\begin{array}{l}\text { congonha-de- } \\
\text { campo-alegre }\end{array}$ & Folha & \begin{tabular}{|l|} 
Macerado em \\
álcool \\
\end{tabular} & Calmante, eupéptico & Arbusto & $\begin{array}{l}\text { Campo } \\
\text { rupestre }\end{array}$ & 1357 \\
\hline $\begin{array}{l}\text { Ilex paraguariensis A. } \\
\text { St.-Hil. }\end{array}$ & erva-mate & Folha e caule & Infuso & Calmante & Arbusto & Floresta & 2223 \\
\hline Ilex sp. & congonha-da-prata & Folha & Decocto & $\begin{array}{l}\text { Para distúrbios vasculares e } \\
\text { calmante. }\end{array}$ & Arbusto & Floresta & 16260 \\
\hline \multicolumn{8}{|l|}{ Araceae } \\
\hline $\begin{array}{l}\text { Colocasia esculenta (L.) } \\
\text { Schott }\end{array}$ & $\begin{array}{c}\text { inhame-branco, } \\
\text { inhame }\end{array}$ & Rizoma & Decocto & $\begin{array}{l}\text { Depurativo, contra afecções } \\
\text { da pele e antirreumático }\end{array}$ & Erva & Cultivado & 26471 \\
\hline $\begin{array}{l}\text { Dieffenbachia seguine } \\
\text { (Jacq.) Schott }\end{array}$ & $\begin{array}{l}\text { comigo-ninguém- } \\
\text { pode }\end{array}$ & Planta toda & & Contra mau-olhado & Erva & Cultivado & 26465 \\
\hline $\begin{array}{l}\text { Xanthosoma taioba } \\
\text { E.G.Gonç. }\end{array}$ & taioba & Folha & Decocto & Antianêmico, tônico & Erva & Cultivado & 26475 \\
\hline \multicolumn{8}{|l|}{ Araliaceae } \\
\hline $\begin{array}{l}\text { Schefflera macrocarpa } \\
\text { (Cham. \& Schltdl.) Frodin }\end{array}$ & mandioca-do-campo & Raiz & Decocto & Antissifilítico & Arbusto & $\begin{array}{l}\text { Campo } \\
\text { rupestre }\end{array}$ & 1319 \\
\hline \multicolumn{8}{|l|}{ Asparagaceae } \\
\hline Asparagus officinalis L. & melindre, melindro & Folha & Infuso & Hipotensor & Erva & Cultivado & 13685 \\
\hline Herreria salsaparilha Mart. & $\begin{array}{c}\text { japecanga, } \\
\text { salsaparrilha }\end{array}$ & Folha e raiz & Decocto & \begin{tabular}{|l}
$\begin{array}{l}\text { Antirreumático, depurativo, } \\
\text { antissifilítico }\end{array}$ \\
\end{tabular} & Liana & Floresta & 1981 \\
\hline $\begin{array}{l}\text { Sansevieria trifasciata } \\
\text { Prain }\end{array}$ & $\begin{array}{l}\text { espada-de-são- } \\
\text { jorge }\end{array}$ & Planta toda & & Contra mau-olhado & Erva & Cultivado & \\
\hline \multicolumn{8}{|l|}{ Asteraceae } \\
\hline \multirow[t]{2}{*}{$\begin{array}{l}\text { Acanthospermum australe } \\
\text { (Loefl.) Kuntze }\end{array}$} & $\begin{array}{l}\text { erva-tostão, fel-da- } \\
\text { terra }\end{array}$ & Raiz & \begin{tabular}{|l|} 
Macerado, \\
mastigar crua
\end{tabular} & Colagogo e colerético & Erva & Ruderal & 7546 \\
\hline & & Parte aérea & $\begin{array}{l}\text { Macerado ou } \\
\text { infuso }\end{array}$ & $\begin{array}{l}\text { Antidiarréico, diurético, } \\
\text { analgésico }\end{array}$ & & & 7546 \\
\hline Achillea millefolium $\mathrm{L}$. & $\begin{array}{l}\text { milefólio, mil-em- } \\
\text { folhas, dipirona, } \\
\text { novalgina, anador }\end{array}$ & Folha & $\begin{array}{l}\text { Infuso ou } \\
\text { macerado }\end{array}$ & $\begin{array}{l}\text { Antipirético, analgésico, } \\
\text { antigripal, anti-hemorroidal, } \\
\text { contra cefaleia }\end{array}$ & Erva & Cultivado & 12682 \\
\hline $\begin{array}{l}\text { Achyrocline satureioides } \\
\text { (Lam.) DC. }\end{array}$ & marcela,macela & Folha e flor & $\begin{array}{l}\text { Infuso ou } \\
\text { macerado }\end{array}$ & Eupéptico, calmante & Erva & $\begin{array}{l}\text { Campo } \\
\text { rupestre }\end{array}$ & 1381 \\
\hline $\begin{array}{l}\text { Acmella oleracea (L.) } \\
\text { R.K.Jansen }\end{array}$ & jambú & Folha & Decocto & \begin{tabular}{|l} 
Hipocolesterolêmico, \\
diurético, hipoglicemiante
\end{tabular} & Erva & Cultivado & 7744 \\
\hline Ageratum conyzoides L. & $\begin{array}{c}\text { erva-de-são } \\
\text { joão, catinga-de- } \\
\text { bode, mentrasto, } \\
\text { mastruço, mastruz, } \\
\text { mentruz } \\
\end{array}$ & Folha & Infuso & $\begin{array}{l}\text { Anticefaléico, antirreumático, } \\
\text { antipirético, antiespasmódico }\end{array}$ & Erva & $\begin{array}{l}\text { Campo } \\
\text { rupestre }\end{array}$ & 15174 \\
\hline Arctium lappa L. & bardana & Raiz & Decocto & $\begin{array}{l}\text { Fortalecimento das raízes } \\
\text { do couro cabeludo, para } \\
\text { afecções gástricas e } \\
\text { hepáticas, depurativo, para } \\
\text { emagrecer, antirreumático e } \\
\text { antissifilítico } \\
\end{array}$ & Erva & Cultivado & 8661 \\
\hline Artemisia absinthium L. & $\begin{array}{l}\text { losna, losma, } \\
\text { absinto, artemijo }\end{array}$ & Folha & $\begin{array}{l}\text { Infuso ou } \\
\text { macerado }\end{array}$ & \begin{tabular}{|l} 
Depurativo, para ressaca \\
alcoólica, antiespasmódico, \\
contra dores estomacais, \\
para afecções gástricas e \\
hepáticas, para amigdalites, \\
expectorante, antidiarréico, \\
antipirético, vermífugo, \\
analgésico, eupéptico e \\
calmante
\end{tabular} & Erva & Cultivado & 8713 \\
\hline Artemisia camphorata Vill. & $\begin{array}{l}\text { alcanfor, artemísia, } \\
\text { artemijo, cânfora, } \\
\text { cânfora-de-jardim, } \\
\text { losna, losna-miúda }\end{array}$ & Parte aérea & $\begin{array}{l}\text { Decocto, infuso } \\
\text { ou macerado }\end{array}$ & $\begin{array}{l}\text { Para insuficiência } \\
\text { respiratória, analgésico, } \\
\text { antiespasmódico, } \\
\text { antidepressivo, antipirético, } \\
\text { antigripal, anti-inflamatório, } \\
\text { para afecções gástricas e } \\
\text { hepáticas, antidiarréico }\end{array}$ & Erva & Cultivado & 8707 \\
\hline
\end{tabular}

Rev. Bras. PI. Med., Campinas, v.17, n.1, p.76-104, 2015. 
TABELA 2. Espécies identificadas como medicinais em levantamento etnobotânico em área urbana no município de Ouro Preto, Minas Gerais, Brasil, 1998-2000. (V = voucher, número de registro no Herbário OUPR, NC = não coletado)

\begin{tabular}{|c|c|c|c|c|c|c|c|}
\hline & & & Alcoolatura & $\begin{array}{l}\text { Uso tópico em dores } \\
\text { musculares, artrites e } \\
\text { reumatismo, anti-inflamatório } \\
\text { em contusões musculares e } \\
\text { para sinusite (inalação) }\end{array}$ & & & \\
\hline & & Folha & Macerado & $\begin{array}{l}\text { Analgésico, béquico, } \\
\text { vermífugo, antiespasmódico, } \\
\text { antianêmico, antidiarréico, } \\
\text { calmante }\end{array}$ & & & \\
\hline Artemisia vulgaris $\mathrm{L}$. & $\begin{array}{l}\text { artemísia, artemijo, } \\
\text { absinto, losna-brava }\end{array}$ & Folha & Infuso & $\begin{array}{l}\text { Antiespasmódico, contra } \\
\text { cólicas menstruais, } \\
\text { antidiarréico }\end{array}$ & Erva & Cultivado & 12681 \\
\hline Artemisia sp. 1 & $\begin{array}{l}\text { artemísia, losna- } \\
\text { miúda }\end{array}$ & Folha & Decocto & Para afecções gástricas & Erva & Cultivado & 15173 \\
\hline Artemisia sp. 2 & artimijo & Folha & Infuso & Antiespasmódico & Erva & Cultivado & 12945 \\
\hline Artemisia sp.3 & artemísia & Folha & Infuso & Antiespasmódico & Erva & Cultivado & 8718 \\
\hline Artemisia sp.4 & artemisia & Folha & Decocto & Antiespasmódico & Erva & Cultivado & 12680 \\
\hline $\begin{array}{l}\text { Baccharis dracunculifolia } \\
\text { DC. }\end{array}$ & $\begin{array}{c}\text { alecrim, } \\
\text { vassourinha, } \\
\text { alecrim-do-campo }\end{array}$ & Parte aérea & $\begin{array}{l}\text { Decocto ou } \\
\text { infuso }\end{array}$ & $\begin{array}{l}\text { Calmante, hipotensor, } \\
\text { broncodilatador, distúrbios } \\
\text { cardiovasculares e antigripal. }\end{array}$ & Erva & $\begin{array}{c}\text { Campo } \\
\text { rupestre }\end{array}$ & 12955 \\
\hline Baccharis crispa Spreng. & carqueja & Parte aérea & $\begin{array}{l}\text { Decocto ou } \\
\text { infuso }\end{array}$ & $\begin{array}{l}\text { Para emagrecimento, } \\
\text { eupéptico, aperiente, } \\
\text { diurético, contra } \\
\text { problemas hepáticos, } \\
\text { vermífugo, eupéptico, para } \\
\text { problemas circulatórios, } \\
\text { hipoglicemiante, anti- } \\
\text { inflamatório. Uso externo } \\
\text { contra ectoparasitas } \\
\text { (piolhos, carrapatos, pulgas } \\
\text { e sarna), contra caspa } \\
\text { e inflamações do couro } \\
\text { cabeludo. } \\
\end{array}$ & Erva & $\begin{array}{l}\text { Campo } \\
\text { rupestre }\end{array}$ & 8276 \\
\hline \multirow[t]{2}{*}{ Bidens pilosa L. } & picão & Planta toda & $\begin{array}{l}\text { Infuso, decocto } \\
\text { ou macerado }\end{array}$ & $\begin{array}{l}\text { Antigripal, calmante, anti- } \\
\text { inflamatório, antianêmico, } \\
\text { para afecções renais e } \\
\text { do trato geniturinário, } \\
\text { estomáquico, para distúrbios } \\
\text { hepáticos, vermífugo, } \\
\text { antigripal, contra hepatite e } \\
\text { depurativo do sangue } \\
\end{array}$ & Erva & Ruderal & 13404 \\
\hline & & Raiz & Decocto & $\begin{array}{l}\text { Antianêmica, contra icterícia } \\
\text { neonatal, afecções renais, } \\
\text { tratamento de hepatite, } \\
\text { vermífugo, diurético } \\
\end{array}$ & & & 13404 \\
\hline Bidens rubifolia Kunth & carrapicho, picão & Folha & Decocto & $\begin{array}{l}\text { Hipoglicemiante e contra } \\
\text { amigdalites }\end{array}$ & Liana & Floresta & 16480 \\
\hline Calendula officinalis $\mathrm{L}$. & $\begin{array}{c}\text { calêndula, mal-me- } \\
\text { quer }\end{array}$ & Folha & Decocto & Para afecções renais & Erva & dontinultizado & 5907 \\
\hline $\begin{array}{l}\text { Chamaemelum nobile } \\
\text { (L.) All. }\end{array}$ & $\begin{array}{l}\text { macelinha, macela, } \\
\text { marcela, macela- } \\
\text { miúda }\end{array}$ & Parte aérea & Macerado & $\begin{array}{l}\text { Antidiarréico, para infecções } \\
\text { intestinais, antipirético, } \\
\text { carminativo, eupéptico, } \\
\text { contra cólicas intestinais } \\
\text { infantis, anticefaléico, } \\
\text { antialérgico, para distúrbios } \\
\text { hepáticos e renais, } \\
\text { vermífugo, analgésico, anti- } \\
\text { inflamatório, antiemético e } \\
\text { antigripal. } \\
\end{array}$ & Erva & Cultivado & 8372 \\
\hline $\begin{array}{l}\text { Chromolaena squalida } \\
\text { (DC.) R.M.King \& H.Rob. }\end{array}$ & erva-de-são-miguel & Folha & Decocto & Béquico, antipirético & Erva & $\begin{array}{l}\text { Campo } \\
\text { rupestre }\end{array}$ & 5415 \\
\hline
\end{tabular}


TABELA 2. Espécies identificadas como medicinais em levantamento etnobotânico em área urbana no município de Ouro Preto, Minas Gerais, Brasil, 1998-2000. (V = voucher, número de registro no Herbário OUPR, NC = não coletado)

\begin{tabular}{|c|c|c|c|c|c|c|c|}
\hline $\begin{array}{l}\text { Chrysanthemum } \\
\text { parthenium (L.) Bernh }\end{array}$ & artemijo & Folha & Infuso & Antiespasmódico, antigripal. & Erva & Cultivado & 7002 \\
\hline $\begin{array}{l}\text { Coreopsis grandiflora } \\
\text { Hogg. ex Sweet }\end{array}$ & camomila & Inflorescência & Infuso & $\begin{array}{l}\text { Antiespasmódico, calmante, } \\
\text { adstringente (uso tópico) }\end{array}$ & Erva & Cultivado & 13400 \\
\hline Cynara scolymus L. & alcachofra & $\begin{array}{c}\text { Folha e } \\
\text { inflorescência }\end{array}$ & Decocto & $\begin{array}{l}\text { Antidiabético, } \\
\text { hipocolesterolêmico, para } \\
\text { afecções renais, distúrbios } \\
\text { hepáticos e dietas para } \\
\text { perda de peso. }\end{array}$ & Erva & Cultivado & NC \\
\hline $\begin{array}{l}\text { Cyrtocymura scorpioides } \\
\text { (Lam.) H.Rob. }\end{array}$ & $\begin{array}{l}\text { erva-preá, erva-de- } \\
\text { coelho }\end{array}$ & Folha & Decocto & $\begin{array}{l}\text { Antisséptico de feridas em } \\
\text { uso externo }\end{array}$ & Erva & $\begin{array}{l}\text { Campo } \\
\text { rupestre }\end{array}$ & 8945 \\
\hline Eclipta prostrata (L.) L. & erva-botão & Parte aérea & Decocto & $\begin{array}{l}\text { Depurativo, } \\
\text { imunoestimulante, contra } \\
\text { picada de cobras }\end{array}$ & Erva & Ruderal & 14333 \\
\hline $\begin{array}{l}\text { Emilia sonchifolia (L.) DC. } \\
\text { ex DC. }\end{array}$ & $\begin{array}{l}\text { pincel-de-estudante, } \\
\text { emília, serralha }\end{array}$ & Folha & Infuso & $\begin{array}{l}\text { Antiasmático, febrífugo, } \\
\text { contra conjuntivites (uso } \\
\text { tópico) }\end{array}$ & Erva & Ruderal & 5626 \\
\hline $\begin{array}{l}\text { Eremanthus } \\
\text { erythropappus (DC.) } \\
\text { MacLeish }\end{array}$ & candeia & Casca do caule & Decocto & $\begin{array}{l}\text { Adstringente, anti- } \\
\text { inflamatório }\end{array}$ & Árvore & Floresta & 12810 \\
\hline Galinsoga parviflora Cav. & botão-de-ouro & Parte aérea & Decocto & Emenagoga & Erva & Ruderal & 26476 \\
\hline $\begin{array}{l}\text { Gymnanthemum } \\
\text { amygdalinum (Delile) Sch. } \\
\text { Bip. ex Walp. }\end{array}$ & $\begin{array}{l}\text { boldo, bordo, } \\
\text { necrotom, boldo- } \\
\text { chinês, boldo-do- } \\
\text { chile, dipirona }\end{array}$ & Folha & $\begin{array}{l}\text { Infuso, } \\
\text { macerado ou } \\
\text { decocto }\end{array}$ & $\begin{array}{l}\text { Para afecções hepáticas } \\
\text { e gástricas, antidiarréico, } \\
\text { emético, analgésico, } \\
\text { contra ressaca alcoólica, } \\
\text { anticefaléico, eupéptico }\end{array}$ & Arbusto & Cultivado & 16892 \\
\hline Lactuca sativa L. & alface & Folha & Infuso ou salada & Calmante & Erva & Cultivado & NC \\
\hline $\begin{array}{l}\text { Lychnophora brunioides } \\
\text { Mart. }\end{array}$ & $\begin{array}{l}\text { arnica, arnica-da- } \\
\text { serra, arnica-do- } \\
\text { campo, }\end{array}$ & Parte aérea & $\begin{array}{l}\text { Alcoolatura (uso } \\
\text { tópico) }\end{array}$ & $\begin{array}{l}\text { Anti-inflamatório, para } \\
\text { contusões e dores } \\
\text { musculares, antirreumático. }\end{array}$ & Arbusto & $\begin{array}{l}\text { Campo } \\
\text { rupestre }\end{array}$ & 26515 \\
\hline $\begin{array}{l}\text { Lychnophora ericoides } \\
\text { Mart. }\end{array}$ & $\begin{array}{l}\text { arnica-da-serra, } \\
\text { arnica-do-campo, } \\
\text { arnica }\end{array}$ & Folha & $\begin{array}{l}\text { Alcoolatura (uso } \\
\text { tópico) }\end{array}$ & $\begin{array}{l}\text { Anti-inflamatório, para } \\
\text { contusões e dores } \\
\text { musculares }\end{array}$ & Arbusto & $\begin{array}{l}\text { Campo } \\
\text { rupestre }\end{array}$ & 9057 \\
\hline Lychnophora sp. & arnica & Parte aérea & $\begin{array}{l}\text { Macerado em } \\
\text { cachaça }\end{array}$ & $\begin{array}{l}\text { Analgésico, para dores } \\
\text { musculares }\end{array}$ & Arbusto & $\begin{array}{c}\text { Campo } \\
\text { rupestre }\end{array}$ & 16274 \\
\hline \multirow[t]{2}{*}{ Matricaria chamomilla L. } & $\begin{array}{l}\text { camomila, } \\
\text { macelinha }\end{array}$ & Planta toda & $\begin{array}{l}\text { Decocto, Infuso } \\
\text { ou macerado }\end{array}$ & $\begin{array}{l}\text { Calmante, anticefaléico, } \\
\text { antipirético, vermífugo, } \\
\text { carminativo, } \\
\text { antiespasmódico, } \\
\text { antiemético, contra sinusite e } \\
\text { afeç̧ões estomacais }\end{array}$ & Erva & Cultivado & 7752 \\
\hline & & Inflorescência & Infuso & $\begin{array}{l}\text { Eupéptico, calmante, laxante } \\
\text { suave }\end{array}$ & & & 7752 \\
\hline $\begin{array}{l}\text { Mikania glomerata } \\
\text { Spreng. }\end{array}$ & guaco, guaiaco & Folha & $\begin{array}{l}\text { Infuso, } \\
\text { macerado, } \\
\text { decocto ou } \\
\text { xarope } \\
\end{array}$ & $\begin{array}{l}\text { Expectorante, antigripal, } \\
\text { diurético para bronquites e } \\
\text { béquico. }\end{array}$ & Liana & Cultivado & 8654 \\
\hline $\begin{array}{l}\text { Pluchea sagittalis (Lam.) } \\
\text { Cabrera }\end{array}$ & quitoco & Folha & Infuso & Analgésico para cefaleias & Erva & Cultivado & 26482 \\
\hline $\begin{array}{l}\text { Senecio brasiliensis } \\
\text { (Spreng.) Less. }\end{array}$ & $\begin{array}{l}\text { cardo-morto, flor- } \\
\text { das-almas }\end{array}$ & Planta toda & Decocto & Vermifugo, emenagogo & Arbusto & $\begin{array}{l}\text { Campo } \\
\text { rupestre }\end{array}$ & 21973 \\
\hline \multirow[t]{2}{*}{ Solidago chilensis Meyen } & arnica, ponta-livre & $\begin{array}{c}\text { Folha e } \\
\text { inflorescência }\end{array}$ & $\begin{array}{l}\text { Macerado em } \\
\text { álcool }\end{array}$ & $\begin{array}{l}\text { Para contusões musculares, } \\
\text { reumatismo e artroses, anti- } \\
\text { inflamatório (uso tópico) } \\
\end{array}$ & Erva & Cultivado & 8745 \\
\hline & & Folha & Infuso & Anticefaléico, antigripal & & & \\
\hline Sonchus oleraceus L. & serralha & Folha & Macerado & $\begin{array}{l}\text { Contra vitiligo, galactagogo, } \\
\text { diurético, laxante }\end{array}$ & Erva & Ruderal & 26467 \\
\hline Tagetes minuta L. & cravo-do-mato & Folha & $\begin{array}{l}\text { Decocto ou } \\
\text { infuso }\end{array}$ & $\begin{array}{l}\text { Emenagogo, para infecções } \\
\text { uterinas }\end{array}$ & Erva & Ruderal & 13002 \\
\hline
\end{tabular}


TABELA 2. Espécies identificadas como medicinais em levantamento etnobotânico em área urbana no município de Ouro Preto, Minas Gerais, Brasil, 1998-2000. (V = voucher, número de registro no Herbário OUPR, NC = não coletado)

\begin{tabular}{|c|c|c|c|c|c|c|c|}
\hline Tanacetum vulgare $\mathrm{L}$. & $\begin{array}{l}\text { catinga-de-mulata, } \\
\text { pluma }\end{array}$ & Folha & Macerado & \begin{tabular}{|l|} 
Descongestionante \\
nasal (para inalações), \\
anticefaléico, para sinusites
\end{tabular} & Erva & Cultivado & 22190 \\
\hline \multirow[t]{2}{*}{$\begin{array}{l}\text { Taraxacum campylodes G. } \\
\text { E. Haglund }\end{array}$} & dente-de-leão & Planta toda & Decocto & \begin{tabular}{|l|} 
Para distúrbios renais, \\
carminativo e contra \\
amigdalites \\
\end{tabular} & Erva & Ruderal & 8373 \\
\hline & & Raiz & Suco & Anti-inflamatório & & & 8373 \\
\hline $\begin{array}{l}\text { Trixis antimenorrhoea } \\
\text { (Schrank) Mart. ex Baker }\end{array}$ & solidônia & Folha & Decocto & \begin{tabular}{|l|}
$\begin{array}{l}\text { Para conjuntivites (uso } \\
\text { tópico) }\end{array}$ \\
\end{tabular} & Liana & Floresta & 3990 \\
\hline $\begin{array}{l}\text { Vernonanthura } \\
\text { phosphorica (Vell.) H.Rob. }\end{array}$ & assapeixe & Folha & $\begin{array}{l}\text { Decocto ou } \\
\text { xarope }\end{array}$ & $\begin{array}{l}\text { Antigripal, diurético, para } \\
\text { afecções pulmonares e } \\
\text { expectorante. }\end{array}$ & Arbusto & $\begin{array}{l}\text { Campo } \\
\text { rupestre }\end{array}$ & 8686 \\
\hline \multicolumn{8}{|l|}{ Balsaminaceae } \\
\hline Impatiens balsamina L. & beijo-branco, beijo & Flor & $\begin{array}{l}\text { Macerado em } \\
\text { vinho }\end{array}$ & $\begin{array}{l}\text { Anti-inflamatório, para } \\
\text { afecções uterinas }\end{array}$ & Erva & Cultivado & 13409 \\
\hline \multicolumn{8}{|l|}{ Begoniaceae } \\
\hline Begonia rufa Thunb. & azedinha-do-brejo & Planta toda & Decocto & Antipirético, antidiarréico & Erva & $\begin{array}{l}\text { Campo } \\
\text { brejoso }\end{array}$ & 10178 \\
\hline Begonia ulmifolia Willd. & sete-sangrias & Folha & Decocto & Hipotensor e antidiarréico. & Erva & Floresta & 8647 \\
\hline \multicolumn{8}{|l|}{ Bignoniaceae } \\
\hline $\begin{array}{l}\text { Handroanthus albus } \\
\text { (Cham.) Mattos }\end{array}$ & ipê-amarelo & Casca do caule & $\begin{array}{l}\text { Decocto ou } \\
\text { alcoolatura }\end{array}$ & Para amigdalites & Árvore & Floresta & 19280 \\
\hline $\begin{array}{l}\text { Jacaranda caroba (Vell.) } \\
\text { DC. }\end{array}$ & carobinha & Raiz & Decocto & $\begin{array}{l}\text { Depurativo, antibiótico, } \\
\text { contra eczemas, diurético } \\
\text { e antirreumático. contra } \\
\text { amebas intestinais } \\
\end{array}$ & Arbusto & $\begin{array}{l}\text { Campo } \\
\text { rupestre }\end{array}$ & 8681 \\
\hline $\begin{array}{l}\text { Pyrostegia venusta (Ker } \\
\text { Grawl.) Miers }\end{array}$ & cipó-de-são-joão & Folha & Infuso & $\begin{array}{l}\text { Antigripal, antirreumático, } \\
\text { tônico, antidiarréico, contra } \\
\text { vitiligo }\end{array}$ & Liana & Floresta & 22113 \\
\hline \multicolumn{8}{|l|}{ Bixaceae } \\
\hline \multirow[t]{2}{*}{ Bixa orellana L. } & urucum & Folha & Decocto & Para amigdalites & Arbusto & Cultivado & 20097 \\
\hline & & Semente & Decocto & Expectorante, febrífugo & & & \\
\hline \multicolumn{8}{|l|}{ Boraginaceae } \\
\hline Borago officinalis $\mathrm{L}$. & borragem & Folha & $\begin{array}{l}\text { Decocto ou } \\
\text { infuso }\end{array}$ & $\begin{array}{l}\text { Para afecções renais e } \\
\text { da bexiga, antirreumático, } \\
\text { hemostático }\end{array}$ & Erva & Cultivado & 3955 \\
\hline Cordia sellowiana Cham. & capitão-do-mato & Folha & Decocto & Para emagrecimento & Árvore & Floresta & 10209 \\
\hline \multirow[t]{2}{*}{ Symphytum officinale L. } & $\begin{array}{c}\text { confrei, borragem, } \\
\text { maria-preta }\end{array}$ & Folha & Macerado & \begin{tabular}{|l|} 
Para afecções gástricas \\
e hepáticas, antigripal, \\
eupéptico. Uso externo como \\
cicatrizante, antisséptico e \\
emoliente em feridas \\
\end{tabular} & Erva & Cultivado & 12669 \\
\hline & & Flor & Infuso & $\begin{array}{l}\text { Antigripal para recém- } \\
\text { nascidos }\end{array}$ & & & \\
\hline $\begin{array}{l}\text { Varronia curassavica } \\
\text { Jacq. }\end{array}$ & $\begin{array}{l}\text { erva-baleeira, } \\
\text { balieira }\end{array}$ & Folha & Decocto & $\begin{array}{l}\text { Cicatrizante para feridas } \\
\text { (uso tópico) }\end{array}$ & Erva & Ruderal & 8807 \\
\hline \multicolumn{8}{|l|}{ Brassicaceae } \\
\hline Brassica oleracea L. & couve & Folha & $\begin{array}{l}\text { Suco e } \\
\text { macerado }\end{array}$ & $\begin{array}{l}\text { Estomáquico, antiácido } \\
\text { e antiúlcera estomacal, } \\
\text { cicatrizante e antigripal. }\end{array}$ & Erva & Cultivado & 7459 \\
\hline Eruca sativa Mill. & rúcula & Folha & \begin{tabular}{|l} 
Ingestão in \\
natura
\end{tabular} & Antigripal & Erva & Cultivado & 26468 \\
\hline Lepidium ruderale L. & mastruz, mastruço & Planta toda & $\begin{array}{l}\text { Liquidificar com } \\
\text { mel e água } \\
\text { (para sinusite), } \\
\text { decocto ou } \\
\text { infuso para } \\
\text { as outras } \\
\text { indicações } \\
\end{array}$ & $\begin{array}{l}\text { Para sinusite, antigripal, } \\
\text { depurativo, diurético, } \\
\text { béquico e contra bronquite. }\end{array}$ & Erva & Ruderal & 4424 \\
\hline
\end{tabular}


TABELA 2. Espécies identificadas como medicinais em levantamento etnobotânico em área urbana no município de Ouro Preto, Minas Gerais, Brasil, 1998-2000. (V = voucher, número de registro no Herbário OUPR, NC = não coletado)

\begin{tabular}{|c|c|c|c|c|c|c|c|}
\hline $\begin{array}{l}\text { Nasturtium officinale } \\
\text { R. Br. }\end{array}$ & agrião & Folha & $\begin{array}{l}\text { Xarope, decocto } \\
\text { ou infuso }\end{array}$ & $\begin{array}{l}\text { Para bronquite e afecções } \\
\text { gástricas, antigripal, } \\
\text { analgésico, béquico, } \\
\text { expectorante }\end{array}$ & Erva & Cultivado & 8753 \\
\hline \multicolumn{8}{|l|}{ Campanulaceae } \\
\hline $\begin{array}{l}\text { Centropogon } \\
\text { surinamensis (L.) C. Presl }\end{array}$ & crista-de-peru & Folha & Decocto & Analgésico em odontalgias & Subarbusto & $\begin{array}{c}\text { Campo } \\
\text { rupestre }\end{array}$ & 1204 \\
\hline \multicolumn{8}{|l|}{ Cannabaceae } \\
\hline $\begin{array}{l}\text { Trema micrantha (L.) } \\
\text { Blume }\end{array}$ & grandiúva & Folha & Decocto & Antirreumático & Árvore & Floresta & 20241 \\
\hline \multicolumn{8}{|l|}{ Caricaceae } \\
\hline \multirow[t]{2}{*}{ Carica papaya L. } & mamão & Flor & Decocto & $\begin{array}{l}\text { Antidiarréico, antiemético, } \\
\text { antigripal (flores), béquico, } \\
\text { para bronquite e afecções } \\
\text { das cordas vocais }\end{array}$ & Árvore & Cultivado & 2367 \\
\hline & & Folha & Decocto & Para afecções estomacais & & & \\
\hline \multicolumn{8}{|l|}{ Caryocaraceae } \\
\hline $\begin{array}{l}\text { Caryocar brasiliense } \\
\text { Cambess. }\end{array}$ & pequi & Fruto & $\begin{array}{l}\text { Macerado em } \\
\text { óleo }\end{array}$ & $\begin{array}{l}\text { Para afecções da pele (uso } \\
\text { tópico) }\end{array}$ & Árvore & Cultivado & 4457 \\
\hline \multicolumn{8}{|l|}{ Celastraceae } \\
\hline $\begin{array}{l}\text { Maytenus ilicifolia Mart. ex } \\
\text { Reissek }\end{array}$ & espinheira-santa & Folha & Infuso & $\begin{array}{l}\text { Carminativo, antiúlcera } \\
\text { estomacal }\end{array}$ & Arbusto & Cultivado & $\mathrm{NC}$ \\
\hline \multicolumn{8}{|l|}{ Chloranthaceae } \\
\hline $\begin{array}{l}\text { Hedyosmum brasiliense } \\
\text { Mart ex Miq. }\end{array}$ & chá-de-soldado & Folha & Alcoolatura & Anti-inflamatório, antipirético & Arbusto & Floresta & 1441 \\
\hline \multicolumn{8}{|l|}{ Cleomaceae } \\
\hline $\begin{array}{l}\text { Tarenaya spinosa (Jacq.) } \\
\text { Raf. }\end{array}$ & mussambê & Folha e flor & $\begin{array}{l}\text { Decocto ou } \\
\text { macerado, } \\
\text { respectivamente } \\
\end{array}$ & $\begin{array}{l}\text { Vulnerário (folhas) e } \\
\text { antitussígeno (flores) }\end{array}$ & Subarbusto & $\begin{array}{l}\text { Campo } \\
\text { rupestre }\end{array}$ & 8896 \\
\hline \multicolumn{8}{|l|}{ Commelinaceae } \\
\hline $\begin{array}{l}\text { Commelina benghalensis } \\
\text { L. }\end{array}$ & marianinha & Folha & Decocto & Anticefaléico, diurético & Erva & $\begin{array}{l}\text { Campo } \\
\text { rupestre }\end{array}$ & 26470 \\
\hline $\begin{array}{l}\text { Tradescantia zebrina } \\
\text { Heynh ex Bosse }\end{array}$ & trapoeraba & Parte aérea & Decocto & Diurético & Erva & Cultivado & 22116 \\
\hline $\begin{array}{l}\text { Tripogandra } \\
\text { serrulata (Vahl) Handlos }\end{array}$ & $\begin{array}{c}\text { trapoeraba-rosa, } \\
\text { marianinha }\end{array}$ & Planta toda & Decocto & Diurético & Erva & $\begin{array}{l}\text { Campo } \\
\text { rupestre }\end{array}$ & 26480 \\
\hline \multicolumn{8}{|l|}{ Convolvulaceae } \\
\hline Cuscuta umbellata Kunth & cipó-chumbo & Caule & $\begin{array}{l}\text { Pó do caule } \\
\text { seco }\end{array}$ & Anti-hemorroidal (uso tópico) & Parasita & $\begin{array}{l}\text { Campo } \\
\text { rupestre }\end{array}$ & 15183 \\
\hline Ipomoea batata Poir & batata-doce & Folha & Decocto & Hipocolesterolêmico & & & 2971 \\
\hline \multicolumn{8}{|l|}{ Costaceae } \\
\hline $\begin{array}{l}\text { Costus comosus (Jacq.) } \\
\text { Roscoe }\end{array}$ & $\begin{array}{c}\text { canela-de-macaco, } \\
\text { caninha-de-macaco, } \\
\text { pacová }\end{array}$ & Folha & Decocto & $\begin{array}{l}\text { Para hemorragias e } \\
\text { afecções renais, diurético, } \\
\text { antirreumático, para } \\
\text { combater o excesso de ácido } \\
\text { úrico }\end{array}$ & Erva & Cultivado & 8697 \\
\hline $\begin{array}{l}\text { Costus spiralis (Jacq.) } \\
\text { Roscoe }\end{array}$ & $\begin{array}{c}\text { caninha-de-macaco, } \\
\text { cana-de-macaco }\end{array}$ & Folha & $\begin{array}{l}\text { Decocto ou } \\
\text { infuso }\end{array}$ & $\begin{array}{l}\text { Para distúrbios renais, } \\
\text { diurético e combater o } \\
\text { excesso de ácido úrico }\end{array}$ & Erva & Cultivado & 13387 \\
\hline \multicolumn{8}{|l|}{ Crassulaceae } \\
\hline $\begin{array}{l}\text { Bryophyllum pinnatum } \\
\text { (Lam.) Oken }\end{array}$ & $\begin{array}{l}\text { bálsamo, saião, } \\
\text { clorama }\end{array}$ & Folha & $\begin{array}{l}\text { In natura, } \\
\text { macerado com } \\
\text { leite }\end{array}$ & $\begin{array}{l}\text { Estomáquico, para afecções } \\
\text { e úlceras gástricas, } \\
\text { para afecções uterinas, } \\
\text { antigripal, contra bronquite, } \\
\text { anti-inflamatório e uso } \\
\text { tópico contra afta, calos, } \\
\text { micoses, picada de inseto, } \\
\text { queimadura, verrugas e otite }\end{array}$ & Erva & Cultivado & 22453 \\
\hline
\end{tabular}


TABELA 2. Espécies identificadas como medicinais em levantamento etnobotânico em área urbana no município de Ouro Preto, Minas Gerais, Brasil, 1998-2000. (V = voucher, número de registro no Herbário OUPR, NC = não coletado)

\begin{tabular}{|c|c|c|c|c|c|c|c|}
\hline Cotyledon orbiculata L. & $\begin{array}{l}\text { bálsamo, baço, } \\
\text { baspo }\end{array}$ & Folha & $\begin{array}{l}\text { Macerado, In } \\
\text { natura }\end{array}$ & $\begin{array}{l}\text { Para afecções gástricas e } \\
\text { hepáticas, antiácido, contra } \\
\text { gastrite, para odontalgias } \\
\text { e otites, eupéptico, } \\
\text { contra hemorragias, anti- } \\
\text { inflamatório, uso tópico como } \\
\text { cicatrizante e emoliente }\end{array}$ & Erva & Cultivado & 22138 \\
\hline $\begin{array}{l}\text { Sedum dendroideum Moc. } \\
\text { \& Sessé ex DC. }\end{array}$ & bálsamo & Folha & In natura & Anti-úlcera gástrica & Erva & Cultivado & 12950 \\
\hline \multicolumn{8}{|l|}{ Cucurbitaceae } \\
\hline Cucumis sativus L. & pepino & Folha & Decocto & Hipotensor & Erva & Cultivado & 7961 \\
\hline Cucurbita pepo L. & abóbora & Semente & \begin{tabular}{|l} 
Trituradas e \\
maceradas em \\
leite de coco \\
\end{tabular} & Vermífugo (tenífugo) & Erva & Cultivado & 8096 \\
\hline \multirow[t]{2}{*}{$\begin{array}{l}\text { Lagenaria } \\
\text { siceraria (Molina) Standl. }\end{array}$} & cabaça & Fruto imaturo & $\begin{array}{l}\text { Ingestão in } \\
\text { natura }\end{array}$ & Purgativo, emenagogo & Liana & Cultivado & 3341 \\
\hline & & Semente & Decocto & $\begin{array}{l}\text { Para nefrites, inchaços das } \\
\text { pernas }\end{array}$ & & & \\
\hline $\begin{array}{l}\text { Luffa operculata (L.) } \\
\text { Cogn. }\end{array}$ & buchinha-do-norte & Fruto & $\begin{array}{l}\text { Decocto } \\
\text { concentrado } \\
\text { (inalação e } \\
\text { instilação nas } \\
\text { narinas) } \\
\end{array}$ & Contra sinusite & Liana & Cultivado & 26464 \\
\hline $\begin{array}{l}\text { Melothrianthus } \\
\text { smilacifolius (Cogn.) Mart. } \\
\text { Crov. }\end{array}$ & cipó-azougue & Raiz & Decocto & $\begin{array}{l}\text { Depurativo, para afecções } \\
\text { da pele }\end{array}$ & Liana & Floresta & 9608 \\
\hline Momordica charantia L. & $\begin{array}{l}\text { melão-de-são- } \\
\text { caetano }\end{array}$ & Folha & $\begin{array}{l}\text { Decocto ou } \\
\text { infuso }\end{array}$ & $\begin{array}{l}\text { Antigripal, vermífugo, para } \\
\text { reduzir o teor de ácido úrico, } \\
\text { diurético, contra bronquite, } \\
\text { uso tópico contra queda } \\
\text { capilar }\end{array}$ & Liana & Ruderal & 10177 \\
\hline & & Fruto & Emplastro & Resolutivo para furúnculos & & & \\
\hline $\begin{array}{l}\text { Sechium edule (Jacq.) } \\
\text { Sw. }\end{array}$ & chuchu & Folha & \begin{tabular}{|l} 
Decocto ou \\
infuso
\end{tabular} & Hipotensor, calmante & Liana & Cultivado & 4001 \\
\hline \multicolumn{8}{|l|}{ Cyatheaceae } \\
\hline Cyathea phalerata Mart. & samambaiaçu & Folha jovem & Decocto & Cicatrizante (uso tópico) & Subarbusto & Floresta & 6820 \\
\hline \multicolumn{8}{|l|}{ Cyperaceae } \\
\hline Cyperus esculentus L. & tiririca & Planta toda & Decocto & Para amigdalite & Erva & Ruderal & 26472 \\
\hline \multicolumn{8}{|l|}{ Dennstaedtiaceae } \\
\hline $\begin{array}{l}\text { Pteridium arachnoideum } \\
\text { (Kaulf.) Maxon }\end{array}$ & $\begin{array}{c}\text { samambaia, broto- } \\
\text { de-samambaia }\end{array}$ & Folha jovem & \begin{tabular}{|l} 
Decocto ou \\
infuso
\end{tabular} & Antirreumático, béquico & Erva & Ruderal & 13598 \\
\hline \multicolumn{8}{|l|}{ Dilleniaceae } \\
\hline Davilla rugosa Poir. & $\begin{array}{l}\text { cipó-caboclo, cipó- } \\
\text { carijó }\end{array}$ & Folha & Decocto & $\begin{array}{l}\text { Colagogo, diurético, } \\
\text { purgativo }\end{array}$ & Liana & Floresta & 10187 \\
\hline \multicolumn{8}{|l|}{ Ebenaceae } \\
\hline \multirow[t]{2}{*}{ Diospyros kaki L. f. } & caqui & Folha & Decocto & Calmante & Árvore & Cultivado & 22827 \\
\hline & & Fruto & $\begin{array}{l}\text { Ingestão in } \\
\text { natura }\end{array}$ & Contra anemia e estomatite & & & \\
\hline \multicolumn{8}{|l|}{ Equisetaceae } \\
\hline Equisetum giganteum L. & $\begin{array}{c}\text { cavalinha, } \\
\text { cavalinha-do-brejo, } \\
\text { caninha-do-brejo, } \\
\text { bambuzinho }\end{array}$ & Planta toda & Decocto & $\begin{array}{l}\text { Para afecções renais e } \\
\text { urinárias, hipoglicemiante, } \\
\text { diurético, para eczemas, } \\
\text { depurativo, antiespasmódico }\end{array}$ & Erva & $\begin{array}{l}\text { Campo } \\
\text { brejoso }\end{array}$ & 9450 \\
\hline \multicolumn{8}{|l|}{ Euphorbiaceae } \\
\hline $\begin{array}{l}\text { Croton antisyphiliticus } \\
\text { Mart. }\end{array}$ & canela-de-perdiz & Raiz & Alcoolatura & $\begin{array}{l}\text { Contra infecções } \\
\text { geniturinárias, antissifilítico }\end{array}$ & Erva & $\begin{array}{l}\text { Campo } \\
\text { rupestre }\end{array}$ & 26458 \\
\hline Croton salutaris Casar. & $\begin{array}{l}\text { sangue-de-drago, } \\
\text { sangra -d'água }\end{array}$ & Folha e látex & $\begin{array}{l}\text { Decocto (folhas) } \\
\text { e uso tópico do } \\
\text { látex }\end{array}$ & $\begin{array}{l}\text { Febrífugo (folhas), contra } \\
\text { úlceras externas (látex) }\end{array}$ & Árvore & Floresta & 1281 \\
\hline
\end{tabular}


TABELA 2. Espécies identificadas como medicinais em levantamento etnobotânico em área urbana no município de Ouro Preto, Minas Gerais, Brasil, 1998-2000. ( V = voucher, número de registro no Herbário OUPR, NC = não coletado)

\begin{tabular}{|c|c|c|c|c|c|c|c|}
\hline Euphorbia prostrata Aiton & $\begin{array}{c}\text { erva-de-santa-luzia, } \\
\text { santa-luzia }\end{array}$ & Parte aérea & Infuso & $\begin{array}{l}\text { Diurético, contra cálculos } \\
\text { renais }\end{array}$ & Erva & Ruderal & 12956 \\
\hline Euphorbia tirucalli L. & avelós, bambuzinho & Látex & Macerado & $\begin{array}{l}\text { Calicida (em uso tópico), } \\
\text { contra câncer }\end{array}$ & Subarbusto & Cultivado & 6690 \\
\hline Jatropha curcas L. & pinhão & Folha & Decocto & $\begin{array}{l}\text { Mau-olhado (uso em } \\
\text { banhos) }\end{array}$ & Arbusto & Cultivado & 9618 \\
\hline Jatropha multifida L. & $\begin{array}{l}\text { anador, dipirona, } \\
\text { novalgina, baspo }\end{array}$ & Folha e caule & $\begin{array}{l}\text { Decocto ou } \\
\text { macerado em } \\
\text { óleo } \\
\end{array}$ & $\begin{array}{l}\text { Dores (uso tópico), anti- } \\
\text { inflamatório, antigripal, } \\
\text { antipirético, anticefaléico }\end{array}$ & Arbusto & Cultivado & 22334 \\
\hline Manihot esculenta Crantz & mandioca & Folha seca & \begin{tabular}{|l|}
$\begin{array}{l}\text { Pó misturado } \\
\text { aos alimentos }\end{array}$ \\
\end{tabular} & Antianêmico & Arbusto & Cultivado & 17109 \\
\hline Ricinus communis $\mathrm{L}$. & mamona & $\begin{array}{l}\text { Óleo da } \\
\text { semente }\end{array}$ & Emplasto & $\begin{array}{l}\text { Resolutivo em furúnculos, } \\
\text { contra ectoparasitas, anti- } \\
\text { inflamatório }\end{array}$ & Arbusto & Ruderal & 6383 \\
\hline \multicolumn{8}{|l|}{ Fabaceae } \\
\hline $\begin{array}{l}\text { Bauhinia cheilantha } \\
\text { (Bong.) Steud. }\end{array}$ & pata-de-vaca & Folha & Decocto & Antidiabético & Árvore & Cultivado & 21990 \\
\hline Bauhinia sp.1 & $\begin{array}{c}\text { pata-de-vaca, unha } \\
\text { de vaca }\end{array}$ & Folha & \begin{tabular}{|l|} 
Decocto ou \\
infuso
\end{tabular} & Hipoglicemiante & Árvore & Floresta & 7403 \\
\hline Bauhinia sp.2 & $\begin{array}{l}\text { pata-de-boi, pata- } \\
\text { de-vaca, unha-de- } \\
\text { vaca }\end{array}$ & $\begin{array}{l}\text { Folha, flor } e \\
\text { casca do caule }\end{array}$ & $\begin{array}{l}\text { Decocto ou } \\
\text { infuso }\end{array}$ & $\begin{array}{l}\text { Hipotensor, para } \\
\text { fortalecimento capilar (uso } \\
\text { tópico) e hipoglicemiante. }\end{array}$ & Árvore & Floresta & 22115 \\
\hline Bauhinia sp.3 & $\begin{array}{l}\text { pata-de-vaca-em- } \\
\text { cipó }\end{array}$ & Folha & Infuso & Hipoglicemiante & Liana & Floresta & 10185 \\
\hline Cajanus cajan (L.) Millsp. & \begin{tabular}{|c|} 
feijão-andu, feijão- \\
guandú, feijão-goma
\end{tabular} & Folha & Infuso & Hemolítico, hipotensor & Arbusto & Cultivado & 22534 \\
\hline Copaifera langsdorfii Desf. & pau-d'óleo, copaíba & $\begin{array}{l}\text { Óleo resina e } \\
\text { casca do caule }\end{array}$ & \begin{tabular}{|l|} 
Decocto da \\
casca ( $\mathrm{p} /$ uso \\
interno) e uso \\
tópico do óleo \\
\end{tabular} & $\begin{array}{l}\text { Antiasmático, para } \\
\text { amigdalite e uso tópico para } \\
\text { eczemas }\end{array}$ & Árvore & Floresta & 26492 \\
\hline Copaifera reticulata Ducke & pau-d'óleo, copaíba & $\begin{array}{l}\text { Cascas e óleo } \\
\text { resina do caule }\end{array}$ & $\begin{array}{l}\text { Óleo extraído do } \\
\text { caule }\end{array}$ & $\begin{array}{l}\text { Para eczemas (em uso } \\
\text { tópico) }\end{array}$ & Árvore & Floresta & 1953 \\
\hline $\begin{array}{l}\text { Desmodium adscendens } \\
\text { (Sw.)DC. }\end{array}$ & $\begin{array}{c}\text { carrapicho beiço- } \\
\text { de-boi, focinho- } \\
\text { de-boi, penicilina, } \\
\text { terramicina } \\
\end{array}$ & $\begin{array}{l}\text { Planta toda ou } \\
\text { folhas }\end{array}$ & $\begin{array}{l}\text { Decocto ou } \\
\text { infuso }\end{array}$ & $\begin{array}{l}\text { Antirreumático, para } \\
\text { afecções renais, antigripal } \\
\text { e uso tópico como anti- } \\
\text { inflamatório } \\
\end{array}$ & Erva & Ruderal & 22404 \\
\hline Hymenaea courbaril L. & jatobá & Folha & Infuso & $\begin{array}{l}\text { Antirreumático e } \\
\text { antiasmático }\end{array}$ & Árvore & Floresta & 8966 \\
\hline $\begin{array}{l}\text { Indigofera suffruticosa } \\
\text { Mill. }\end{array}$ & anileira & $\begin{array}{c}\text { Folha, raiz e } \\
\text { semente }\end{array}$ & Decocto & \begin{tabular}{|l|} 
Estomáquico, \\
antiespasmódico e sedativo
\end{tabular} & Subarbusto & $\begin{array}{c}\text { Campo } \\
\text { rupestre }\end{array}$ & 12124 \\
\hline Inga sessilis (Vell.) Mart. & ingá, angá & Casca do caule & Decocto & $\begin{array}{l}\text { Antidiarréico, antirreumático, } \\
\text { anti-helmíntico }\end{array}$ & Árvore & Floresta & 1439 \\
\hline $\begin{array}{l}\text { Melanoxylon brauna } \\
\text { Schott }\end{array}$ & braúna & Casca do caule & Decocto & $\begin{array}{l}\text { Antidiarréico, anti- } \\
\text { hemorrágico }\end{array}$ & Árvore & Floresta & 7405 \\
\hline Mimosa dolens Vell. & unha-de-gato & Parte aérea & Infuso & Analgésico em mialgias & Arbusto & Floresta & 12803 \\
\hline $\begin{array}{l}\text { Piptadenia gonoacantha } \\
\text { (Mart.) J.F.Macbr }\end{array}$ & angico & Casca do caule & Decocto & $\begin{array}{l}\text { Béquico, anti-inflamatório } \\
\text { dos ovários }\end{array}$ & Árvore & Floresta & 20287 \\
\hline $\begin{array}{l}\text { Piptadenia gonoacantha } \\
\text { (Mart.) J.F.Macbr }\end{array}$ & angico & Casca do caule & Decocto & \begin{tabular}{|l} 
Béquico, anti-inflamatório \\
dos ovários \\
\end{tabular} & Árvore & Floresta & 20287 \\
\hline Senna alexandrina Mill. & sene & Folha & $\begin{array}{l}\text { Decocto ou } \\
\text { infuso }\end{array}$ & Laxante & Arbusto & Cultivado & 22114 \\
\hline $\begin{array}{l}\text { Piptadenia gonoacantha } \\
\text { (Mart.) J.F.Macbr }\end{array}$ & angico & Casca do caule & Decocto & $\begin{array}{l}\text { Béquico, anti-inflamatório } \\
\text { dos ovários } \\
\end{array}$ & Árvore & Floresta & 20287 \\
\hline Senna alexandrina Mill. & sene & Folha & \begin{tabular}{|l}
$\begin{array}{l}\text { Decocto ou } \\
\text { infuso }\end{array}$ \\
\end{tabular} & Laxante & Arbusto & Cultivado & 22114 \\
\hline $\begin{array}{l}\text { Piptadenia gonoacantha } \\
\text { (Mart.) J.F.Macbr }\end{array}$ & angico & Casca do caule & Decocto & $\begin{array}{l}\text { Béquico, anti-inflamatório } \\
\text { dos ovários }\end{array}$ & Árvore & Floresta & 20287 \\
\hline $\begin{array}{l}\text { Deianira nervosa Cham. } \\
\text { \& Schltdl. }\end{array}$ & centáurea- do-brasil & Planta toda & Infuso & $\begin{array}{l}\text { Eupéptico, aperiente, } \\
\text { vermífugo }\end{array}$ & Erva & $\begin{array}{l}\text { Campo } \\
\text { rupestre }\end{array}$ & 1464 \\
\hline
\end{tabular}


TABELA 2. Espécies identificadas como medicinais em levantamento etnobotânico em área urbana no município de Ouro Preto, Minas Gerais, Brasil, 1998-2000. (V = voucher, número de registro no Herbário OUPR, NC = não coletado)

...continuação

\begin{tabular}{|c|c|c|c|c|c|c|c|}
\hline \multicolumn{8}{|l|}{ Geraniaceae } \\
\hline $\begin{array}{l}\text { Pelargonium radula (Cav.) } \\
\text { L' Hér. }\end{array}$ & $\begin{array}{l}\text { malva-rosa, malva- } \\
\text { cheirosa, malvinha, } \\
\text { malva }\end{array}$ & Folha & $\begin{array}{l}\text { Decocto ou } \\
\text { infuso }\end{array}$ & $\begin{array}{l}\text { Para afecções cardíacas, } \\
\text { béquico, anti-inflamatório, } \\
\text { para bronquites e infecções } \\
\text { uterinas, calmante, } \\
\text { expectorante, hipotensor } \\
\text {, antigripal, em gargarejos } \\
\text { para amigdalites e gengivites }\end{array}$ & Erva & Cultivado & 8376 \\
\hline $\begin{array}{l}\text { Pelargonium } \\
\text { odoratissimum (L.) L'Hér. }\end{array}$ & malva, malvinha & Folha & $\begin{array}{l}\text { Decocto ou } \\
\text { infuso }\end{array}$ & $\begin{array}{l}\text { Em bochechos para } \\
\text { gengivite e amidalite }\end{array}$ & Erva & Cultivado & 13399 \\
\hline \multicolumn{8}{|l|}{ Hypericaceae } \\
\hline $\begin{array}{l}\text { Vismia magnoliifolia } \\
\text { Cham. \& Schltdl. }\end{array}$ & pau-de-lacre & $\begin{array}{l}\text { Látex, goma- } \\
\text { resina }\end{array}$ & $\begin{array}{l}\text { In natura, } \\
\text { diluição em água }\end{array}$ & $\begin{array}{l}\text { Purgativo, vulnerário, } \\
\text { febrífugo }\end{array}$ & Arbusto & Floresta & 1216 \\
\hline \multicolumn{8}{|l|}{ Lamiaceae } \\
\hline Glechoma hederacea L. & $\begin{array}{l}\text { erva-terrestre, } \\
\text { erva-de-são-joão, } \\
\text { hortelã-do-mato, } \\
\text { erva- silvestre }\end{array}$ & Planta toda & $\begin{array}{l}\text { Decocto ou } \\
\text { infuso }\end{array}$ & $\begin{array}{l}\text { Béquico, antigripal, } \\
\text { antidiarreico, antirreumático, } \\
\text { contra infecções intestinais, } \\
\text { eupéptico e expectorante. }\end{array}$ & Erva & Cultivado & 8964 \\
\hline $\begin{array}{l}\text { Lavandula } \\
\text { angustifolia Mill. }\end{array}$ & alfazema & Folha & $\begin{array}{l}\text { Decocto ou } \\
\text { infuso }\end{array}$ & $\begin{array}{l}\text { Para bronquite, antiasmático } \\
\text { e uso tópico para afecções } \\
\text { da pele }\end{array}$ & Erva & Cultivado & 22161 \\
\hline $\begin{array}{l}\text { Leonotis nepetifolia (L.) } \\
\text { R.Br. }\end{array}$ & $\begin{array}{l}\text { cordão-de-são- } \\
\text { francisco }\end{array}$ & Folha & $\begin{array}{l}\text { Macerado em } \\
\text { água }\end{array}$ & Contra distúrbios hepáticos & Erva & Ruderal & 26514 \\
\hline Leonurus japonicus Houtt. & $\begin{array}{c}\text { macaé, lavadeira, } \\
\text { erva-das-lavadeiras, } \\
\text { besouro, joao- } \\
\text { serafim, homem- } \\
\text { sem-dinheiro, } \\
\text { mané-magro, isopo, } \\
\text { pango, micaela, } \\
\text { laçavenha, flor de } \\
\text { besouro }\end{array}$ & Folha & $\begin{array}{l}\text { Macerado, } \\
\text { decocto ou } \\
\text { infuso }\end{array}$ & $\begin{array}{l}\text { Eupéptico, antidiarréico, } \\
\text { para afecções cardíacas e } \\
\text { respiratórias, anticefaléico, } \\
\text { antiespasmódico, } \\
\text { antipirético béquico, } \\
\text { hipotensor, hemolítico, } \\
\text { antigripal, depurativo, } \\
\text { hipocolesterolêmico, } \\
\text { para distúrbios hepáticos } \\
\text { e gástricos, antiácido, } \\
\text { antiemético, aperiente, } \\
\text { antiemético, para distúrbios } \\
\text { renais e circulatórios }\end{array}$ & Erva & Ruderal & 8669 \\
\hline Melissa officinalis L & $\begin{array}{l}\text { cidreira, erva- } \\
\text { cidreira, erva- } \\
\text { cidreira-da-horta, } \\
\text { melissa }\end{array}$ & Folha & Infuso & $\begin{array}{l}\text { Calmante, antiespasmódico, } \\
\text { antigripal, antidiarréico, } \\
\text { para afecções gástricas, } \\
\text { hepáticas e uterinas, } \\
\text { béquico, contra bronquite, } \\
\text { analgésico em odontalgias, }\end{array}$ & Erva & Cultivado & 8645 \\
\hline Mentha longifolia (L.) L. & $\begin{array}{c}\text { levante, elevante, } \\
\text { alevante }\end{array}$ & $\begin{array}{c}\text { Folha e planta } \\
\text { toda }\end{array}$ & $\begin{array}{l}\text { Decocto, } \\
\text { macerado, } \\
\text { infuso ou infuso } \\
\text { com gordura } \\
\end{array}$ & $\begin{array}{l}\text { Antigripal, broncodilatador, } \\
\text { para bronquite, eupéptico, } \\
\text { para espinhela caída e } \\
\text { estomáquico. }\end{array}$ & Erva & Cultivado & 8691 \\
\hline Mentha pulegium L. & $\begin{array}{c}\text { poejo, poejo-branco, } \\
\text { erva-terrestre }\end{array}$ & Planta toda & $\begin{array}{l}\text { Decocto, Infuso } \\
\text { ou infuso com } \\
\text { gordura }\end{array}$ & $\begin{array}{l}\text { Antigripal, béquico, } \\
\text { antidiarréico, expectorante, } \\
\text { para bronquite, eupéptico, } \\
\text { antiemético, antiácido, } \\
\text { para afecções gástricas, } \\
\text { antidepressivo e calmante. }\end{array}$ & Erva & Cultivado & 12424 \\
\hline Mentha spicata L. & $\begin{array}{c}\text { manjerona, } \\
\text { poejinho, poejo }\end{array}$ & Folha & $\begin{array}{l}\text { Decocto ou } \\
\text { infuso }\end{array}$ & $\begin{array}{l}\text { Antigripal, catártico, } \\
\text { antidiarréico, béquico, } \\
\text { para afecções das cordas } \\
\text { vocais, faringites,laringites e } \\
\text { amigdalites }\end{array}$ & Erva & Cultivado & 7683 \\
\hline Mentha suaveolens Ehrh. & vick & Folha & Infuso & Para amigdalite & Erva & Cultivado & 4536 \\
\hline
\end{tabular}


TABELA 2. Espécies identificadas como medicinais em levantamento etnobotânico em área urbana no município de Ouro Preto, Minas Gerais, Brasil, 1998-2000. (V = voucher, número de registro no Herbário OUPR, NC = não coletado)

...continuação

\begin{tabular}{|c|c|c|c|c|c|c|c|}
\hline Mentha $\mathrm{x}$ villosa Huds & hortelã & Folha & Infuso & $\begin{array}{l}\text { Vermífugo, antigripal, } \\
\text { antibiótico, para amigdalite, } \\
\text { antidiarreico, para cefaleias } \\
\text { e anginas, antipirético, } \\
\text { antiespasmódico, calmante, } \\
\text { antiemético, laxante, para } \\
\text { afecções gástricas }\end{array}$ & Erva & Cultivado & 6853 \\
\hline Mentha sp.1 & $\begin{array}{l}\text { levante, alevante, } \\
\text { elevante }\end{array}$ & Folha & $\begin{array}{l}\text { Infuso com água } \\
\text { ou leite }\end{array}$ & \begin{tabular}{|l} 
Para afecções da pele e \\
gástricas, antidiarréico, \\
para otite, espinhela caída, \\
antidepressivo, antigripal, \\
vermífugo, antiespasmódico, \\
anti-inflamatório, \\
contra cálculos biliares, \\
galactagogo, para aumentar \\
a fertilidade da mulher \\
\end{tabular} & Erva & Cultivado & 6970 \\
\hline Mentha sp.2 & hortelã & Folha & Infuso & $\begin{array}{l}\text { Antigripal, antiespasmódico, } \\
\text { para afecções estomacais e } \\
\text { hepáticas, anti-inflamatório, } \\
\text { galactagogo, vermífugo, } \\
\text { antidiarréico, calmante, para } \\
\text { espinhela caída, béquico, } \\
\text { vermífugo, eupéptico, } \\
\text { analgésico, para leucorréias } \\
\text { e gengivite, anti-inflamatório } \\
\text { da garganta, galactagogo, } \\
\text { distúrbios cardiovasculares, } \\
\text { hidratante e antirreumático. }\end{array}$ & Erva & Cultivado & 8370 \\
\hline Ocimum basilicum L. & alfavaca & Folha e flor & Decocto, infuso & Béquico, antigripal. & Subarbusto & Cultivado & 3971 \\
\hline $\begin{array}{l}\text { Ocimum carnosum } \\
\text { (Spreng.) Link \& Otto ex } \\
\text { Benth }\end{array}$ & $\begin{array}{c}\text { alfavaca, canelinha, } \\
\text { elevante, alfavaca- } \\
\text { canela, manjericão- } \\
\text { roxo }\end{array}$ & Folha & $\begin{array}{l}\text { Decocto ou } \\
\text { infuso }\end{array}$ & $\begin{array}{l}\text { Antigripal, contra afecções } \\
\text { da boca e garganta, béquico, } \\
\text { expectorante, para afecções } \\
\text { cardíacas, antiasmático, } \\
\text { para espinhela caída } \\
\end{array}$ & Subarbusto & Cultivado & 8337 \\
\hline Ocimum gratissimum L. & $\begin{array}{l}\text { alfavaca, canelinha, } \\
\text { alfavaca-grande, } \\
\text { alfavaca-cravo, } \\
\text { favaquinha, favaca }\end{array}$ & Folha & $\begin{array}{l}\text { Infuso, decocto } \\
\text { ou xarope }\end{array}$ & $\begin{array}{l}\text { Antigripal, para gastrites, } \\
\text { antianêmico, calmante, } \\
\text { béquico, expectorante, } \\
\text { contra afecções da boca e } \\
\text { garganta }\end{array}$ & Subarbusto & Cultivado & 7749 \\
\hline Ocimum minimum $\mathrm{L}$. & manjericão & Folha & $\begin{array}{l}\text { Decocto ou } \\
\text { infuso }\end{array}$ & $\begin{array}{l}\text { Calmante, analgésico para } \\
\text { dores lombares, antigripal, } \\
\text { eupéptico. }\end{array}$ & Subarbusto & Cultivado & 6973 \\
\hline Ocimum sp.1 & $\begin{array}{l}\text { alfavaca, dipirona, } \\
\text { novalgina, anador, } \\
\text { manjericão, } \\
\text { manjericão-branco, } \\
\text { alfavaca }\end{array}$ & Folha & $\begin{array}{l}\text { Macerado, } \\
\text { infuso, decocto, } \\
\text { xarope, infuso } \\
\text { com gordura }\end{array}$ & $\begin{array}{l}\text { Gargarejos contra afecções } \\
\text { da boca e garganta, } \\
\text { antigripal, béquico, calmante, } \\
\text { antitérmico, anticefaléico, } \\
\text { expectorante, analgésico } \\
\text { e anti-inflamatório, para } \\
\text { bronquite, para afecções } \\
\text { cardíacas, antiasmático, } \\
\text { eupéptico, contra mau- } \\
\text { olhado }\end{array}$ & Subarbusto & Cultivado & 7585 \\
\hline Ocimum sp.2 & manjericão-roxo & Folha & \begin{tabular}{|l|} 
Infuso, decocto \\
ou macerado
\end{tabular} & $\begin{array}{l}\text { Calmante, antigripal, contra } \\
\text { afecções cardíacas, béquico }\end{array}$ & Subarbusto & Cultivado & 8658 \\
\hline Origanum majorana L. & manjerona & Planta toda & $\begin{array}{l}\text { Decocto, Infuso } \\
\text { ou infuso com } \\
\text { gordura, como } \\
\text { condimento }\end{array}$ & $\begin{array}{l}\text { Antigripal, expectorante, } \\
\text { vermífugo, para afecções } \\
\text { gástricas, eupéptico, } \\
\text { calmante e béquico, para } \\
\text { bronquite, contra cólicas } \\
\text { dos recém-nascidos, } \\
\text { para afecções cardíacas, } \\
\text { antidiarréico }\end{array}$ & Erva & Cultivado & 8676 \\
\hline
\end{tabular}

Rev. Bras. PI. Med., Campinas, v.17, n.1, p.76-104, 2015. 
TABELA 2. Espécies identificadas como medicinais em levantamento etnobotânico em área urbana no município de Ouro Preto, Minas Gerais, Brasil, 1998-2000. (V = voucher, número de registro no Herbário OUPR, NC = não coletado)

...continuação

\begin{tabular}{|c|c|c|c|c|c|c|c|}
\hline Origanum vulgare L. & orégano & $\begin{array}{c}\text { Folha e } \\
\text { brácteas da } \\
\text { inflorescência }\end{array}$ & $\begin{array}{l}\text { Infuso, } \\
\text { macerado, como } \\
\text { condimento } \\
\end{array}$ & Eupéptico & Erva & Cultivado & 7583 \\
\hline $\begin{array}{l}\text { Plectranthus amboinicus } \\
\text { (Lour.) Spreng. }\end{array}$ & hortelã-pimenta & Folha & $\begin{array}{l}\text { Decocto ou } \\
\text { infuso }\end{array}$ & $\begin{array}{l}\text { Antidiarréico, vermífugo, } \\
\text { antigripal, eupeptico }\end{array}$ & Subarbusto & Cultivado & 8272 \\
\hline $\begin{array}{l}\text { Plectranthus barbatus } \\
\text { Andrews }\end{array}$ & $\begin{array}{l}\text { boldo, bordo, boldo- } \\
\text { japonês, boldo- } \\
\text { macho }\end{array}$ & Folha & $\begin{array}{l}\text { Macerado ou } \\
\text { infuso }\end{array}$ & $\begin{array}{l}\text { Para afecções hepáticas e } \\
\text { gástricas, contra ressaca } \\
\text { alcoólica, antidiarréico, } \\
\text { anticefaléico, carminativo, } \\
\text { antiemético, expectorante, } \\
\text { antiácido, eupéptico, contra } \\
\text { afecções da pele, hipotensor, } \\
\text { para taquicardia }\end{array}$ & Subarbusto & Cultivado & 8682 \\
\hline $\begin{array}{l}\text { Plectranthus neochilus } \\
\text { Schltr. }\end{array}$ & $\begin{array}{l}\text { boldo-miúdo, boldo- } \\
\text { gambá, boldo- } \\
\text { japonês, estomalina }\end{array}$ & Folha & $\begin{array}{l}\text { Macerado ou } \\
\text { infuso }\end{array}$ & $\begin{array}{l}\text { Para afecções hepáticas e } \\
\text { gástricas, contra ressaca } \\
\text { alcoólica, antidiarréico, } \\
\text { anticefaléico, carminativo, } \\
\text { antiemético, expectorante, } \\
\text { antiácido, eupéptico, } \\
\text { hipotensor, para taquicardia }\end{array}$ & Erva & Cultivado & 6982 \\
\hline $\begin{array}{l}\text { Plectranthus } \\
\text { scutellarioides (L.) R.Br. }\end{array}$ & sangue-de- cristo & Folha & Infuso & Calmante & Subarbusto & Cultivado & 21974 \\
\hline Rosmarinus officinalis L. & $\begin{array}{l}\text { alecrim, alecrim-de- } \\
\text { casa, alecrim-da- } \\
\text { horta }\end{array}$ & Folha & $\begin{array}{l}\text { Decocto ou } \\
\text { infuso }\end{array}$ & $\begin{array}{l}\text { Para taquicardia e angina } \\
\text { e insuficiência cardíaca, } \\
\text { cardiotônico, broncodilatador, } \\
\text { distúrbios cardiovasculares, } \\
\text { hipotensor, antidiarréico, } \\
\text { antigripal, contra apneia e } \\
\text { asma, calmante, béquico, } \\
\text { antidepressivo, contra } \\
\text { sinusite, depurativo, } \\
\text { anticefaléico e para } \\
\text { odontalgias }\end{array}$ & Subarbusto & Cultivado & 8274 \\
\hline Salvia officinalis $\mathrm{L}$. & sálvia, salva & Folha & Infuso & $\begin{array}{l}\text { Eupéptico, para afeç̧ões da } \\
\text { boca e garganta }\end{array}$ & Erva & Cultivado & 8377 \\
\hline Stachys byzantina K.Koch & $\begin{array}{l}\text { salva, sálvia, peixe- } \\
\text { frito, lambari }\end{array}$ & Folha & Infuso & $\begin{array}{l}\text { Antiemético, para afecções } \\
\text { estomacais, amigdalite } \\
\text { afecções gástricas. da boca } \\
\text { e da garganta e rouquidão, } \\
\text { anticefaléico, béquico, } \\
\text { antigripal, antidiarréico, } \\
\text { antipirético, contra bronquite, } \\
\text { para reposição hormonal das } \\
\text { mulheres em menopausa }\end{array}$ & Erva & Cultivado & 8752 \\
\hline Vitex polygama Cham. & $\begin{array}{c}\text { azeitona-do-mato, } \\
\text { azeitona-do-campo, } \\
\text { tarumã, mamica-de- } \\
\text { cadela } \\
\end{array}$ & Casca do caule & Decocto & $\begin{array}{l}\text { Depurativo, para tratamento } \\
\text { de vitiligo }\end{array}$ & Árvore & Floresta & 20169 \\
\hline \multicolumn{8}{|l|}{ Lauraceae } \\
\hline $\begin{array}{l}\text { Cinnamomum verum J. } \\
\text { Presl. }\end{array}$ & canela & Casca do caule & Infuso & Má-digestão & Árvore & Floresta & 18103 \\
\hline Persea americana Mill. & abacateiro & Folha & $\begin{array}{l}\text { Decocto ou } \\
\text { infuso }\end{array}$ & $\begin{array}{l}\text { Calmante, para distúrbios } \\
\text { renais, diurético e contra o } \\
\text { excesso de ácido úrico }\end{array}$ & Árvore & Cultivado & 6173 \\
\hline \multicolumn{8}{|l|}{ Loranthaceae } \\
\hline $\begin{array}{l}\text { Psittacanthus dichroos } \\
\text { (Mart.) Mart. }\end{array}$ & erva-de-passarinho & Folha & $\begin{array}{l}\text { Decocto ou } \\
\text { emplastro (uso } \\
\text { tópico) }\end{array}$ & $\begin{array}{l}\text { Resolutivo, para afecções } \\
\text { catarrais das vias } \\
\text { respiratórias }\end{array}$ & Parasita & Floresta & 1371 \\
\hline $\begin{array}{l}\text { Struthanthus concinnus } \\
\text { Mart. }\end{array}$ & pelipoteca-cheirosa & Folha & Emplastro & $\begin{array}{l}\text { Resolutivo para furúnculos } \\
\text { e cicatrizante para outras } \\
\text { afecções da pele }\end{array}$ & Parasita & Floresta & 9275 \\
\hline
\end{tabular}


TABELA 2. Espécies identificadas como medicinais em levantamento etnobotânico em área urbana no município de Ouro Preto, Minas Gerais, Brasil, 1998-2000. (V = voucher, número de registro no Herbário OUPR, NC = não coletado)

...continuação

\begin{tabular}{|c|c|c|c|c|c|c|c|}
\hline Sthruthanthus sp. & erva de passarinho & Folha & Decocto & Para pneumonia & Parasita & Floresta & 20165 \\
\hline \multicolumn{8}{|l|}{ Lycopodiaceae } \\
\hline $\begin{array}{l}\text { Lycopodiella cernua (L.) } \\
\text { Pic.Serm. }\end{array}$ & $\begin{array}{l}\text { licopódio, pé-de- } \\
\text { lobo }\end{array}$ & Planta toda & $\begin{array}{l}\text { Decocto, } \\
\text { esporos secos }\end{array}$ & $\begin{array}{l}\text { Diurético, vulnerário, } \\
\text { cicatrizante (uso tópico) em } \\
\text { feridas da pele }\end{array}$ & Erva & $\begin{array}{l}\text { Campo } \\
\text { rupestre }\end{array}$ & 23261 \\
\hline Lycopodium clavatum L. & $\begin{array}{l}\text { licopódio, pé-de- } \\
\text { lobo }\end{array}$ & Planta toda & \begin{tabular}{|l} 
Decocto, \\
esporos secos
\end{tabular} & $\begin{array}{l}\text { Diurético, cicatrizante (uso } \\
\text { tópico) em feridas da pele }\end{array}$ & Erva & $\begin{array}{l}\text { Campo } \\
\text { rupestre }\end{array}$ & 15225 \\
\hline \multicolumn{8}{|l|}{ Lythraceae } \\
\hline $\begin{array}{l}\text { Cuphea ingrata Cham. \& } \\
\text { Schltdl. }\end{array}$ & sete-sangrias & Folha & Infuso & Hipotensor, antitérmico & Subarbusto & $\begin{array}{l}\text { Campo } \\
\text { rupestre }\end{array}$ & 9279 \\
\hline Lafoensia pacari A.St.-Hil. & pacarí & Raiz & Decocto & Febrifugo, tônico & Árvore & $\begin{array}{l}\text { Campo } \\
\text { rupestre }\end{array}$ & 7764 \\
\hline Punica granatum $\mathrm{L}$. & romã & Folha e fruto & Decocto & $\begin{array}{l}\text { Em gargarejos para } \\
\text { amigdalite, para afecções } \\
\text { da boca e da garganta e uso } \\
\text { interno como antidiarréico e } \\
\text { vermífugo }\end{array}$ & Arbusto & Cultivado & 12679 \\
\hline \multicolumn{8}{|l|}{ Malpighiaceae } \\
\hline $\begin{array}{l}\text { Banisteriopsis campestris } \\
\text { (A. Juss.) Little }\end{array}$ & murici & Folha & Decocto & Febrifugo, béquico & Liana & $\begin{array}{l}\text { Campo } \\
\text { rupestre }\end{array}$ & 5592 \\
\hline $\begin{array}{l}\text { Banisteriopsis harleyi B. } \\
\text { Gates }\end{array}$ & cipó-prata & Folha e caule & Decocto & Para afecções renais & Liana & $\begin{array}{l}\text { Campo } \\
\text { rupestre }\end{array}$ & 13255 \\
\hline $\begin{array}{l}\text { Byrsonima intermedia A. } \\
\text { Juss. }\end{array}$ & canjica, murici & Casca do caule & Decocto & Adstringente, béquico & Arbusto & $\begin{array}{l}\text { Campo } \\
\text { rupestre }\end{array}$ & 1277 \\
\hline $\begin{array}{l}\text { Byrsonima variabilis A. } \\
\text { Juss. }\end{array}$ & murici & Folha & Decocto & Adstringente, febrífugo & Arbusto & $\begin{array}{l}\text { Campo } \\
\text { rupestre }\end{array}$ & 9315 \\
\hline \multicolumn{8}{|l|}{ Malvaceae } \\
\hline Althaea sp. & altéia, malvarisco & Folha & Infuso & $\begin{array}{l}\text { Anti-inflamatório, } \\
\text { expectorante, para afecções } \\
\text { da boca e da garganta }\end{array}$ & Erva & Cultivado & 10217 \\
\hline Gossypium arboreum L. & algodão & Semente & Decocto & \begin{tabular}{|l|} 
Contra cálculos biliares e \\
infecções renais
\end{tabular} & Arbusto & Cultivado & 22108 \\
\hline \multirow[t]{3}{*}{ Gossypium herbaceum L. } & algodão & Folha & $\begin{array}{l}\text { Decocto ou } \\
\text { infuso }\end{array}$ & $\begin{array}{l}\text { Anti-inflamatório, para } \\
\text { perda de peso e infecções } \\
\text { dermatológicas urinárias, } \\
\text { uterinas e da próstata, otite } \\
\text { (uso tópico), antibiótico, } \\
\text { analgésico em odontalgias, } \\
\text { anti-hemorrágico, para } \\
\text { recuperação pós parto, } \\
\text { contra cálculos biliares, } \\
\text { antidiarréico, } \\
\end{array}$ & Subarbusto & Cultivado & 12686 \\
\hline & & Flor & Infuso & Para otite (uso tópico) & & & \\
\hline & & Semente & \begin{tabular}{|l|} 
Infuso com \\
3 sementes \\
torradas
\end{tabular} & $\begin{array}{l}\text { Analgésico tópico da gengiva } \\
\text { no crescimento de dentes de } \\
\text { crianças, antidiarréico }\end{array}$ & & & \\
\hline Malva moschata L. & $\begin{array}{l}\text { malva, malvinha, } \\
\text { malva-rosa, malva- } \\
\text { branca }\end{array}$ & Planta toda & $\begin{array}{l}\text { Decocto ou } \\
\text { infuso }\end{array}$ & $\begin{array}{l}\text { Calmante, béquico e anti- } \\
\text { inflamatório da boca e } \\
\text { garganta, antidiarréico, } \\
\text { contra taquicardia, } \\
\text { hipotensor, resolutivo e } \\
\text { emoliente em abscesso e } \\
\text { furúnculos }\end{array}$ & Erva & Cultivado & 8368 \\
\hline Sida rhombifolia L. & $\begin{array}{l}\text { guanxuma, } \\
\text { vassoura }\end{array}$ & Folha & Decocto & Resolutivo, anti-inflamatório & Erva & $\begin{array}{l}\text { Campo } \\
\text { rupestre }\end{array}$ & 1231 \\
\hline $\begin{array}{l}\text { Triumfetta semitriloba } \\
\text { Jacq. }\end{array}$ & carrapicho & Planta toda & Decocto & Depurativo & Erva & $\begin{array}{l}\text { Campo } \\
\text { rupestre }\end{array}$ & 4012 \\
\hline \multicolumn{8}{|l|}{ Melastomataceae } \\
\hline Clidemia urceolata DC. & pixirica & Folha & Infuso & $\begin{array}{l}\text { Para combater ectoparasitas } \\
\text { (uso tópico) }\end{array}$ & Arbusto & $\begin{array}{c}\text { Campo } \\
\text { rupestre }\end{array}$ & 26460 \\
\hline
\end{tabular}


TABELA 2. Espécies identificadas como medicinais em levantamento etnobotânico em área urbana no município de Ouro Preto, Minas Gerais, Brasil, 1998-2000. (V = voucher, número de registro no Herbário OUPR, NC = não coletado)

...continuação

\begin{tabular}{|c|c|c|c|c|c|c|c|}
\hline $\begin{array}{l}\text { Miconia theizans (Bonpl.) } \\
\text { Cogn. }\end{array}$ & jacatirão & Folha & Decocto & Estimulante, antidepressivo & Arbusto & Floresta & 17327 \\
\hline Tococa sp. & erva-sapateira & Folha & $\begin{array}{l}\text { Decocto ou } \\
\text { infuso }\end{array}$ & $\begin{array}{l}\text { Contra escabiose (uso } \\
\text { tópico) }\end{array}$ & Arbusto & Floresta & 5602 \\
\hline \multicolumn{8}{|l|}{ Meliaceae } \\
\hline $\begin{array}{l}\text { Cabralea canjerana (Vell.) } \\
\text { Mart. }\end{array}$ & canjerana & Raiz & Decocto & $\begin{array}{l}\text { Antipirético, adstringente, } \\
\text { emético }\end{array}$ & Arbusto & Floresta & 9413 \\
\hline \multicolumn{8}{|l|}{ Menispermaceae } \\
\hline Abuta sp. & abútua & Raiz & Decocto & $\begin{array}{l}\text { Emenagogo, antipirético, } \\
\text { tônico }\end{array}$ & Liana & Floresta & 7397 \\
\hline $\begin{array}{l}\text { Cissampelos } \\
\text { andromorpha DC. }\end{array}$ & $\begin{array}{l}\text { uva-do-mato, } \\
\text { abútua }\end{array}$ & Folha & Decocto & Para distúrbios renais & Liana & Floresta & 10197 \\
\hline \multicolumn{8}{|l|}{ Moraceae } \\
\hline \multirow[t]{2}{*}{ Ficus carica L. } & figo & Infrutescência & \begin{tabular}{|l|} 
Ingestão in \\
natura
\end{tabular} & Laxante, expectorante & Arbusto & Cultivado & 7979 \\
\hline & & Folha & Decocto & Expectorante & & & \\
\hline Morus alba L. & $\begin{array}{l}\text { amora, amora- } \\
\text { branca }\end{array}$ & Folha & $\begin{array}{l}\text { Decocto ou } \\
\text { infuso }\end{array}$ & $\begin{array}{l}\text { Para reposição } \\
\text { hormonal, calmante, } \\
\text { antidiarréico, diurético, } \\
\text { hipocolesterolêmico, para } \\
\text { amigdalite } \\
\end{array}$ & Arbusto & Cultivado & 26466 \\
\hline $\begin{array}{l}\text { Sorocea bonplandii (Baill.) } \\
\text { W.C.Burger \& de Boer }\end{array}$ & espinheira-santa & Folha & Infuso & $\begin{array}{l}\text { Carminativo, antiúlcera } \\
\text { estomacal }\end{array}$ & Árvore & Floresta & 16306 \\
\hline \multicolumn{8}{|l|}{ Musaceae } \\
\hline Musa x paradisiaca $\mathrm{L}$. & bananeira & $\begin{array}{l}\text { Folhas } \\
\text { (bainhas) }\end{array}$ & \begin{tabular}{|l|} 
Mucilagem \\
diluída em água
\end{tabular} & $\begin{array}{l}\text { Expectorante, para bronquite } \\
\text { e asma }\end{array}$ & Erva & Cultivado & $\mathrm{NC}$ \\
\hline \multicolumn{8}{|l|}{ Myrtaceae } \\
\hline $\begin{array}{l}\text { Corymbia citriodora } \\
\text { (Hook.) K.D.Hill \& } \\
\text { L.A.S.Johnson }\end{array}$ & eucalipto & Folha & Decocto & Para sinusite (em inalações) & Árvore & Cultivado & 2268 \\
\hline Eucalyptus sp. & eucalipto & Folha & Decocto & \begin{tabular}{|l|} 
Béquico, antigripal, \\
broncodilatador, contra \\
sinusite, gengivite, \\
anti-inflamatório, \\
descongestionante nasal \\
(inalações) \\
\end{tabular} & Árvore & Cultivado & 8755 \\
\hline Eugenia uniflora L. & pitanga & Folha & $\begin{array}{l}\text { Decocto ou } \\
\text { infuso }\end{array}$ & $\begin{array}{l}\text { Para amigdalite, } \\
\text { antidiarréico, eupéptico, } \\
\text { vermífugo, para afecções } \\
\text { da pele }\end{array}$ & Arbusto & Cultivado & 12942 \\
\hline $\begin{array}{l}\text { Plinia peruviana (Poir.) } \\
\text { Govaerts }\end{array}$ & jaboticaba & Folha & Decocto & Hipoglicemiante & Arbusto & Cultivado & 26510 \\
\hline Psidium firmum O.Berg. & araçá & Folha & Decocto & Anti-inflamatório & Arbusto & $\begin{array}{l}\text { Campo } \\
\text { rupestre }\end{array}$ & 7552 \\
\hline Psidium guajava L. & goiabeira & $\begin{array}{c}\text { Folha e casca } \\
\text { do caule }\end{array}$ & Decocto & $\begin{array}{l}\text { Antidiarréico, anti- } \\
\text { inflamatório, estomáquico, } \\
\text { contra afecções da boca } \\
\text { e da garganta, para } \\
\text { odontalgias e cistite, contra } \\
\text { placa bacteriana nos dentes }\end{array}$ & Arbusto & Cultivado & 8756 \\
\hline $\begin{array}{l}\text { Syzygium aromaticum (L.) } \\
\text { Merr. \& L.M. Perry }\end{array}$ & cravo & $\begin{array}{c}\begin{array}{c}\text { Folha e botão } \\
\text { floral }\end{array} \\
\end{array}$ & \begin{tabular}{|l|}
$\begin{array}{l}\text { Decocto ou } \\
\text { infuso }\end{array}$ \\
\end{tabular} & Antigripal e calmante & Árvore & Cultivado & 23878 \\
\hline $\begin{array}{l}\text { Syzygium jambos (L.) } \\
\text { Alston }\end{array}$ & jambo & Folha & Decocto & Hipocolesterolêmico & Árvore & Cultivado & 1752 \\
\hline \multicolumn{8}{|l|}{ Nyctaginaceae } \\
\hline Boerhavia diffusa $\mathrm{L}$ & erva-tostão & Raiz & $\begin{array}{l}\text { Macerado, } \\
\text { Ingestão in } \\
\text { natura }\end{array}$ & $\begin{array}{l}\text { Colagogo e colerético, } \\
\text { eupéptico, para manchas } \\
\text { da pele, antigripal, diurético, } \\
\text { antidiarréico }\end{array}$ & Erva & Ruderal & 12932 \\
\hline
\end{tabular}


TABELA 2. Espécies identificadas como medicinais em levantamento etnobotânico em área urbana no município de Ouro Preto, Minas Gerais, Brasil, 1998-2000. (V = voucher, número de registro no Herbário OUPR, NC = não coletado)

...continuação

\begin{tabular}{|c|c|c|c|c|c|c|c|}
\hline & & Folha & Infuso & $\begin{array}{l}\text { Analgésico tópico da gengiva } \\
\text { no crescimento de dentes de } \\
\text { crianças, antidiarréico, anti- } \\
\text { inflamatório }\end{array}$ & & & \\
\hline \multirow[t]{2}{*}{ Mirabilis jalapa L. } & maravilha, bonina & Folha & Emplasto & $\begin{array}{l}\text { Resolutivo para furúnculos } \\
\text { (uso tópico) }\end{array}$ & Erva & Cultivado & 4419 \\
\hline & & Raiz & $\begin{array}{l}\text { Macerado em } \\
\text { água }\end{array}$ & Purgante & & & \\
\hline \multicolumn{8}{|l|}{ Ochnaceae } \\
\hline Sauvagesia erecta L. & $\begin{array}{l}\text { erva-de-são- } \\
\text { martinho }\end{array}$ & Flor & Infuso & $\begin{array}{l}\text { Diurético e contra } \\
\text { conjuntivite }\end{array}$ & Erva & $\begin{array}{l}\text { Campo } \\
\text { rupestre }\end{array}$ & 7373 \\
\hline \multicolumn{8}{|l|}{ Oxalidaceae } \\
\hline \multirow[t]{2}{*}{ Averrhoa carambola L. } & carambola & Fruto & Suco & $\begin{array}{l}\text { Hipocolesterolêmico, } \\
\text { hipoglicemiante }\end{array}$ & Árvore & Cultivado & 24584 \\
\hline & & Folha & $\begin{array}{l}\text { Decocto ou } \\
\text { infuso }\end{array}$ & $\begin{array}{l}\text { Hemolítico, hipoglicemiante, } \\
\text { hipocolesterolêmico }\end{array}$ & & & \\
\hline \multicolumn{8}{|l|}{ Papaveraceae } \\
\hline Argemone mexicana L. & cardo-santo & Folha e caule & Infuso & $\begin{array}{l}\text { Antiasmático, contra } \\
\text { conjuntivite, eczemas e } \\
\text { resolutivo em furúnculos }\end{array}$ & Erva & Cultivado & 2200 \\
\hline Fumaria officinalis $L$. & fumária & Planta toda & Infuso & Para afecções gástricas & Erva & Ruderal & 4449 \\
\hline \multicolumn{8}{|l|}{ Passifloraceae } \\
\hline Passiflora alata Curtis & maracujá & Folha & Infuso & Calmante, ansiolítico & Liana & Floresta & 3983 \\
\hline Passiflora edulis Sims & maracujá & Folha & Infuso & $\begin{array}{l}\text { Antigripal, calmante, } \\
\text { ansiolítico }\end{array}$ & Liana & Cultivado & 8716 \\
\hline $\begin{array}{l}\text { Passiflora haematostigma } \\
\text { Mart. ex Mast. }\end{array}$ & maracujá-do-mato & Folha & Infuso & $\begin{array}{l}\text { Sonífero, calmante, } \\
\text { ansiolítico }\end{array}$ & Liana & Floresta & 17051 \\
\hline Passiflora villosa Vell. & maracujá & Folha & Decocto & Calmante & Liana & $\begin{array}{l}\text { Campo } \\
\text { rupestre }\end{array}$ & 15196 \\
\hline \multicolumn{8}{|l|}{ Phyllanthaceae } \\
\hline Phyllanthus niruri L. & quebra-pedra & Planta toda & $\begin{array}{l}\text { Decocto ou } \\
\text { infuso }\end{array}$ & $\begin{array}{l}\text { Para afecções renais e } \\
\text { hepáticas, contra cálculos } \\
\text { renais, antigripal, calmante, } \\
\text { anti-inflamatório, contra } \\
\text { gastrite inflamações } \\
\text { urinárias, antiespasmódico, } \\
\text { diurético } \\
\end{array}$ & Erva & Ruderal & 22458 \\
\hline Phyllanthus sp. & quebra-pedra & Planta toda & $\begin{array}{l}\text { Decocto ou } \\
\text { infuso }\end{array}$ & $\begin{array}{l}\text { Para afecções renais e } \\
\text { hepáticas, contra cálculos } \\
\text { renais, contra inflamações } \\
\text { urinárias, diurético }\end{array}$ & Erva & Ruderal & 8703 \\
\hline \multicolumn{8}{|l|}{ Phytolaccaceae } \\
\hline Petiveria alliacea L. & guiné & Parte aérea & Decocto & $\begin{array}{l}\text { Descarrego, mau-olhado } \\
\text { (banho), anti-inflamatório, } \\
\text { antibiótico, para gengivite }\end{array}$ & Erva & Cultivado & 22140 \\
\hline $\begin{array}{l}\text { Phytolacca thyrsiflora } \\
\text { Fenzl. ex J.A.Schmidt }\end{array}$ & $\begin{array}{c}\text { caruru-bravo, } \\
\text { caruru-de-pomba }\end{array}$ & $\begin{array}{c}\text { Folha, fruto e } \\
\text { raiz }\end{array}$ & Emplasto & Drástico, resolutivo & Erva & Ruderal & 4014 \\
\hline \multicolumn{8}{|l|}{ Piperaceae } \\
\hline Piper mollicomum Kunth & jaborandí & Folha & $\begin{array}{l}\text { Decocto ou } \\
\text { macerado }\end{array}$ & Tônico capilar (uso tópico) & Arbusto & Ruderal & 15277 \\
\hline Piper umbellatum L. & $\begin{array}{l}\text { capeba, caopeba, } \\
\text { pariparoba, } \\
\text { capibaroba }\end{array}$ & Folha & Infuso & $\begin{array}{l}\text { Antigripal, para afecções } \\
\text { hepáticas, estomáquico, } \\
\text { diurético, para distúrbios } \\
\text { renais e das vias urinárias, } \\
\text { antidiarréico, para reduzir o } \\
\text { teor de ácido úrico, contra } \\
\text { hidropisias }\end{array}$ & Subarbusto & $\begin{array}{l}\text { Campo } \\
\text { rupestre }\end{array}$ & 26478 \\
\hline
\end{tabular}


TABELA 2. Espécies identificadas como medicinais em levantamento etnobotânico em área urbana no município de Ouro Preto, Minas Gerais, Brasil, 1998-2000. (V = voucher, número de registro no Herbário OUPR, NC = não coletado)

...continuação

\begin{tabular}{|c|c|c|c|c|c|c|c|}
\hline \multicolumn{8}{|l|}{ Plantaginaceae } \\
\hline Plantago major L. & $\begin{array}{l}\text { transagem, } \\
\text { tanchagem }\end{array}$ & Planta toda & Decocto & $\begin{array}{l}\text { Anti-inflamatório, antibiótico, } \\
\text { para infecções da boca, } \\
\text { garganta, urinárias, } \\
\text { ginecológicas e oculares, } \\
\text { diurético, analgésico, } \\
\text { antigripal, cicatrizante, } \\
\text { eupéptico, antiulcera } \\
\text { gástrica, contra cálculos } \\
\text { renais, contra hidropisias, } \\
\text { antiespasmódico }\end{array}$ & Erva & Ruderal & 22122 \\
\hline Plantago tomentosa Lam. & $\begin{array}{c}\text { transagem, } \\
\text { tanchagem, língua- } \\
\text { de-vaca }\end{array}$ & Planta toda & $\begin{array}{l}\text { Decocto ou } \\
\text { infuso }\end{array}$ & $\begin{array}{l}\text { Anti-inflamatório, antibiótico, } \\
\text { para infecções da boca, } \\
\text { garganta, urinárias, } \\
\text { ginecológicas e oculares, } \\
\text { diurético, analgésico, } \\
\text { antigripal, cicatrizante, } \\
\text { eupéptico, antiulcera } \\
\text { gástrica, contra cálculos } \\
\text { renais, contra hidropisias, } \\
\text { cicatrizante de feridas (uso } \\
\text { tópico) }\end{array}$ & Erva & Ruderal & 8689 \\
\hline Scoparia dulcis L. & $\begin{array}{l}\text { vassourinha- } \\
\text { do-campo, } \\
\text { vassourinha-doce, } \\
\text { vassoura-doce }\end{array}$ & Folha e raiz & $\begin{array}{l}\text { Decocto ou } \\
\text { infuso }\end{array}$ & $\begin{array}{l}\text { Emoliente, expectorante, } \\
\text { anti-inflamatório, contra } \\
\text { cálculos renais, antigripal, } \\
\text { para conjuntivites (uso } \\
\text { tópico) }\end{array}$ & Erva & Ruderal & 13398 \\
\hline \multicolumn{8}{|l|}{ Poaceae } \\
\hline Andropogon bicornis L. & capim-rabo-de burro & Raiz & Decocto & Emoliente, colagogo & Erva & Ruderal & 1498 \\
\hline $\begin{array}{l}\text { Andropogon } \\
\text { leucostachyus Kunth }\end{array}$ & capim-rabo-de-burro & Raiz & Decocto & $\begin{array}{l}\text { Diurético, emoliente, } \\
\text { diaforético }\end{array}$ & Erva & $\begin{array}{l}\text { Campo } \\
\text { rupestre }\end{array}$ & 26459 \\
\hline Coix lacryma-jobi L. & $\begin{array}{l}\text { lágrimas-de-nossa- } \\
\text { senhora, conta-de- } \\
\text { lágrima, cana-do- } \\
\text { reino } \\
\end{array}$ & Folha & Decocto & $\begin{array}{l}\text { Para infecções urinárias, } \\
\text { diurético, béquico, anti- } \\
\text { hemorrágico, eupéptico, para } \\
\text { perda de peso }\end{array}$ & Erva & Cultivado & 8679 \\
\hline $\begin{array}{l}\text { Cymbopogom citratus } \\
\text { (DC.) Stapf }\end{array}$ & $\begin{array}{l}\text { capim-cidreira, } \\
\text { cidreira, capim- } \\
\text { limão capim-santo, } \\
\text { erva-cidreira, erva- } \\
\text { cidreira-de-capim, }\end{array}$ & Folha & $\begin{array}{l}\text { Infuso ou } \\
\text { macerado }\end{array}$ & $\begin{array}{l}\text { Antigripal, diurético, } \\
\text { hipotensor, calmante, para } \\
\text { afecções renais, béquico, } \\
\text { hipotensor, antiespasmódico } \\
\text { em cólicas menstruais, } \\
\text { antipirético }\end{array}$ & Erva & Cultivado & 8720 \\
\hline $\begin{array}{l}\text { Cymbopogon densiflorus } \\
\text { (Steud.) Stapf }\end{array}$ & capim-de-são-josé & Folha & Decocto & $\begin{array}{l}\text { Contra dores musculares } \\
\text { (uso tópico) }\end{array}$ & Erva & Cultivado & 14101 \\
\hline $\begin{array}{l}\text { Melinis minutiflora } \\
\text { P.Beauv. }\end{array}$ & capim-gordura & Planta toda & Decocto & Antirreumático & Erva & Ruderal & 16225 \\
\hline $\begin{array}{l}\text { Parodiolyra micrantha } \\
\text { (Kunth) Davidse \& } \\
\text { Zuloaga }\end{array}$ & taboca & Planta toda & Decocto & Diurético & Erva & $\begin{array}{l}\text { Campo } \\
\text { rupestre }\end{array}$ & 1499 \\
\hline $\begin{array}{l}\text { Pennisetum setosum } \\
\text { (Sw.) Rich. }\end{array}$ & capim-de-prata & Raiz & Decocto & Emoliente, diurético & Erva & $\begin{array}{c}\text { Campo } \\
\text { rupestre }\end{array}$ & 1501 \\
\hline Phalaris canariensis L. & alpiste & Fruto & Decocto & Hipotensor & Erva & Cultivado & 13460 \\
\hline Saccharum officinarum L. & cana & Folha & $\begin{array}{l}\text { Decocto ou } \\
\text { infuso }\end{array}$ & $\begin{array}{l}\text { Béquico, diurético, anti- } \\
\text { hemorrágico, hipotensor, } \\
\text { antiasmático }\end{array}$ & Erva & Cultivado & 13508 \\
\hline Zea mays L. & milho & Estilete/estigma & $\begin{array}{l}\text { Decocto ou } \\
\text { infuso }\end{array}$ & $\begin{array}{l}\text { Diurético, para afecções } \\
\text { renais }\end{array}$ & Erva & Cultivado & 13515 \\
\hline \multicolumn{8}{|l|}{ Polygalaceae } \\
\hline $\begin{array}{l}\text { Bredemeyera velutina } \\
\text { A.W.Benn. }\end{array}$ & $\begin{array}{l}\text { cervejinha-do- } \\
\text { campo }\end{array}$ & Raiz & $\begin{array}{l}\text { Macerado ou } \\
\text { decocto }\end{array}$ & Para afecções renais & Liana & $\begin{array}{l}\text { Campo } \\
\text { rupestre }\end{array}$ & 20736 \\
\hline
\end{tabular}


TABELA 2. Espécies identificadas como medicinais em levantamento etnobotânico em área urbana no município de Ouro Preto, Minas Gerais, Brasil, 1998-2000. (V = voucher, número de registro no Herbário OUPR, NC = não coletado)

...continuação

\begin{tabular}{|c|c|c|c|c|c|c|c|}
\hline Polygala paniculata L. & gelol & Planta toda & Alcoolatura & $\begin{array}{l}\text { Analgésico, contra dores } \\
\text { musculares e reumatismo } \\
\text { (uso tópico) }\end{array}$ & Erva & $\begin{array}{l}\text { Campo } \\
\text { rupestre }\end{array}$ & 9511 \\
\hline Polygala timoutou Aubl. & timotu, gelol & Raiz & Decocto & $\begin{array}{l}\text { Diurético, emenagogo, } \\
\text { emético }\end{array}$ & Erva & $\begin{array}{c}\text { Campo } \\
\text { rupestre }\end{array}$ & 1425 \\
\hline \multicolumn{8}{|l|}{ Polygonaceae } \\
\hline $\begin{array}{l}\text { Polygonum punctatum } \\
\text { Elliotth }\end{array}$ & erva-de-bicho & Planta toda & Decocto & $\begin{array}{l}\text { Anti-hemorroidal (uso interno } \\
\text { e tópico). }\end{array}$ & Erva & $\begin{array}{l}\text { Campo } \\
\text { rupestre }\end{array}$ & 7751 \\
\hline Rheum palmatum $\mathrm{L}$. & ruibarbo & Raiz & $\begin{array}{l}\text { Macerado em } \\
\text { cachaça ou } \\
\text { decocto }\end{array}$ & $\begin{array}{l}\text { Laxativo, purgativo, } \\
\text { aperiente (em pequenas } \\
\text { doses) }\end{array}$ & Erva & Cultivado & $\mathrm{NC}$ \\
\hline Rumex obtusifolius L. & labaça, babaça & Folha & Decocto & Antigripal & Erva & Ruderal & 6195 \\
\hline \multicolumn{8}{|l|}{ Portulacaceae } \\
\hline Portulaca oleracea L. & beldroega & Parte aérea & Decocto & $\begin{array}{l}\text { Galactagogo, diurético e } \\
\text { vermífugo }\end{array}$ & Erva & Ruderal & 26491 \\
\hline \multicolumn{8}{|l|}{ Proteaceae } \\
\hline Roupala montana Aubl. & carne-de-vaca & Semente & Emplasto & $\begin{array}{l}\text { Resolutivo para furúnculos } \\
\text { (uso tópico) }\end{array}$ & Arbusto & $\begin{array}{c}\text { Campo } \\
\text { rupestre }\end{array}$ & 17408 \\
\hline \multicolumn{8}{|l|}{ Pteridaceae } \\
\hline $\begin{array}{l}\text { Adiantum raddianum } \\
\text { C.Presl }\end{array}$ & avenca & Folha & Infuso & Expectorante & Erva & Floresta & 17690 \\
\hline \multicolumn{8}{|l|}{ Ranunculaceae } \\
\hline Clematis dioica L. & barba-de-velho & Raiz & Decocto & Diurético, drástico & Liana & Floresta & 1355 \\
\hline $\begin{array}{l}\text { Ranunculus bonariensis } \\
\text { Poir. }\end{array}$ & botão-de-ouro & Planta toda & Decocto & $\begin{array}{l}\text { Uso tópico contra } \\
\text { ectoparasitas }\end{array}$ & Erva & Cultivado & 7740 \\
\hline Ranunculus bulbosus L. & botão-de-ouro & Planta toda & Decocto & Analgésico & Erva & Cultivado & 8275 \\
\hline \multicolumn{8}{|l|}{ Rosaceae } \\
\hline Agrimonia eupatoria L. & agrimônia & Folha & Infuso & $\begin{array}{l}\text { Analgésico, vermífugo, } \\
\text { calmante }\end{array}$ & Erva & Cultivado & NC \\
\hline $\begin{array}{l}\text { Eriobotrya japonica } \\
\text { (Thunb.) Lindl. }\end{array}$ & ameixa & Folha & Decocto & Hipotensor, calmante & Arbusto & Cultivado & 8303 \\
\hline Fragaria vesca $\mathrm{L}$. & morango, fragária & Folha & Decocto & \begin{tabular}{|l} 
Anti-inflamatório, \\
antidiarréico
\end{tabular} & Erva & Cultivado & 7533 \\
\hline Fragaria sp. & fragaia & Parte aérea & Decocto & $\begin{array}{l}\text { Para reduzir o teor de ácido } \\
\text { úrico }\end{array}$ & Erva & Ruderal & 7534 \\
\hline Rosa centifolia L. & rosa-branca & Pétala & \begin{tabular}{|l|} 
Decocto ou \\
infuso com leite
\end{tabular} & $\begin{array}{l}\text { Hipotensor, antibiótico e anti- } \\
\text { inflamatório, depurativo }\end{array}$ & Arbusto & Cultivado & 26513 \\
\hline Rosa sp. & rosa-branca & Flor & Infuso com leite & $\begin{array}{l}\text { Para inflamações de pele } \\
\text { (acne e furunculose), anti- } \\
\text { inflamatório, antibiótico, } \\
\text { anti-hemorroidal. Uso tópico } \\
\text { como anti-inflamatório em } \\
\text { feridas }\end{array}$ & Arbusto & Cultivado & 22126 \\
\hline Rubus brasiliensis Mart & amora-preta & Folha e raiz & Decocto & $\begin{array}{l}\text { Adstringente, } \\
\text { antiespasmódico, diurético }\end{array}$ & Arbusto & $\begin{array}{l}\text { Campo } \\
\text { rupestre }\end{array}$ & 1373 \\
\hline \multicolumn{8}{|l|}{ Rubiaceae } \\
\hline $\begin{array}{l}\text { Bathysa australis (A.St.- } \\
\text { Hil.) K.Schum. }\end{array}$ & quina-do-mato & Casca do caule & Decocto & Febrífugo, tônico & Arbusto & Floresta & 19289 \\
\hline $\begin{array}{l}\text { Borreria capitata (Ruiz \& } \\
\text { Pav.) DC. }\end{array}$ & poaia-do-campo & Raiz & Decocto & Emético & Erva & Ruderal & 12796 \\
\hline $\begin{array}{l}\text { Borreria verticillata (L.) } \\
\text { G. Mey. }\end{array}$ & poaia, ipeca & Raiz & Decocto & $\begin{array}{l}\text { Béquico, expectorante e } \\
\text { emético }\end{array}$ & Erva & Ruderal & 12797 \\
\hline $\begin{array}{l}\text { Carapichea ipecacuanha } \\
\text { (Brot.) L.Andersson }\end{array}$ & ipeca, poaia & Raiz & Xarope & $\begin{array}{l}\text { Antigripal, contra asma e } \\
\text { bronquite }\end{array}$ & Subarbusto & Floresta & 10388 \\
\hline \multirow[t]{2}{*}{ Coffea arabica L. } & café & Flor & Infuso & Antigripal & Arbusto & Cultivado & 8043 \\
\hline & & Folha & Infuso & Antipirético & & & \\
\hline $\begin{array}{l}\text { Cordiera elliptica (Cham.) } \\
\text { Kuntze }\end{array}$ & marmelinho & Folha & Decocto & $\begin{array}{l}\text { Diurético, para afecções } \\
\text { renais }\end{array}$ & Arbusto & $\begin{array}{c}\text { Campo } \\
\text { rupestre }\end{array}$ & 9284 \\
\hline
\end{tabular}


TABELA 2. Espécies identificadas como medicinais em levantamento etnobotânico em área urbana no município de Ouro Preto, Minas Gerais, Brasil, 1998-2000. (V = voucher, número de registro no Herbário OUPR, NC = não coletado)

...continuação

\begin{tabular}{|c|c|c|c|c|c|c|c|}
\hline Genipa americana L. & jenipapo & Folha e raiz & $\begin{array}{l}\text { Decocto ou } \\
\text { infuso }\end{array}$ & $\begin{array}{l}\text { Para expelir cálculos renais, } \\
\text { contra cólicas renais e outros } \\
\text { distúrbios urinários }\end{array}$ & Árvore & Floresta & 12941 \\
\hline $\begin{array}{l}\text { Palicourea marcgravii } \\
\text { A.St.-Hil. }\end{array}$ & erva-de-rato & Folha & Decocto & Antidisúrico (uso veterinário) & Subarbusto & $\begin{array}{l}\text { Campo } \\
\text { rupestre }\end{array}$ & 1402 \\
\hline Palicourea rigida Kunth & bate-caixa & Folha & Decocto & $\begin{array}{l}\text { Calmante, diurético, } \\
\text { antirreumático }\end{array}$ & Subarbusto & $\begin{array}{l}\text { Campo } \\
\text { rupestre }\end{array}$ & 22494 \\
\hline Palicourea sp. & congonha-do-gentio & Folha & Decocto & $\begin{array}{l}\text { Calmante, diurético e para } \\
\text { distúrbios renais }\end{array}$ & Arbusto & $\begin{array}{l}\text { Campo } \\
\text { rupestre }\end{array}$ & 1251 \\
\hline $\begin{array}{l}\text { Palicourea tetraphylla } \\
\text { Cham. \& Schltdl. }\end{array}$ & $\begin{array}{l}\text { congonha-bate- } \\
\text { caixa }\end{array}$ & Folha & Decocto & Diurético & Subarbusto & $\begin{array}{l}\text { Campo } \\
\text { rupestre }\end{array}$ & 1262 \\
\hline
\end{tabular}

Rutaceae

\begin{tabular}{|c|c|c|c|c|c|c|c|}
\hline Citrus aurantium L. & laranja & Folha & $\begin{array}{l}\text { Decocto ou } \\
\text { infuso com água } \\
\text { ou leite }\end{array}$ & $\begin{array}{l}\text { Calmante, antigripal, } \\
\text { béquico, anticefaléico, } \\
\text { antipirético, hipotensor, } \\
\text { depurativo }\end{array}$ & Arbusto & Cultivado & 7697 \\
\hline Citrus limetta Risso & lima & Folha & Macerado & Calmante, diurético & Arbusto & Cultivado & 7668 \\
\hline Citrus limonum Risso & limão & $\begin{array}{l}\text { Folha, flor e } \\
\text { fruto }\end{array}$ & $\begin{array}{l}\text { Xarope, decocto } \\
\text { ou infuso }\end{array}$ & $\begin{array}{l}\text { Béquico, antigripal, } \\
\text { broncodilatador, calmante }\end{array}$ & Arbusto & Cultivado & 2284 \\
\hline Citrus medica L. & cidra & Fruto & Infuso & Antigripal & Arbusto & Cultivado & 9534 \\
\hline Citrus reticulata Blanco & mexerica & Folha & Decocto & Antigripal & Arbusto & Cultivado & 7695 \\
\hline Ruta graveolens L. & arruda & Folha & $\begin{array}{l}\text { Infuso ou } \\
\text { macerado }\end{array}$ & $\begin{array}{l}\text { Contra amenorreia, } \\
\text { carminativo, } \\
\text { antiespasmódico, contra } \\
\text { nevralgias, vermífugo, } \\
\text { antirreumático. Uso tópico } \\
\text { contra conjuntivite, anti- } \\
\text { inflamatório de feridas da } \\
\text { pele e no tratamento de } \\
\text { ectoparasitas (escabiose). } \\
\text { Banhos contra mau olhado e } \\
\text { descarrego }\end{array}$ & Subarbusto & Cultivado & 7054 \\
\hline $\begin{array}{l}\text { Zanthoxylum rhoifolium } \\
\text { Lam. }\end{array}$ & mamica-de-porca & Casca do caule & Decocto & $\begin{array}{l}\text { Tônico, contra odontalgia, } \\
\text { antibiótico, febrífugo }\end{array}$ & Árvore & Floresta & 2274 \\
\hline \multicolumn{8}{|l|}{ Salicaceae } \\
\hline Casearia sylvestris Sw. & $\begin{array}{c}\text { guaçatonga, língua- } \\
\text { de-tiú }\end{array}$ & $\begin{array}{l}\text { Folha e casca } \\
\text { do caule }\end{array}$ & Decocto & $\begin{array}{l}\text { Hipocolesterolêmico, } \\
\text { depurativo e contra bronquite } \\
\text { asmática }\end{array}$ & Árvore & $\begin{array}{l}\text { Campo } \\
\text { rupestre }\end{array}$ & 6424 \\
\hline \multicolumn{8}{|l|}{ Sapindaceae } \\
\hline Paullinia cupana Kunth & guaraná & Semente & $\begin{array}{l}\text { Trituradas e } \\
\text { misturadas com } \\
\text { água }\end{array}$ & $\begin{array}{l}\text { Estimulante, eupéptico, } \\
\text { antidiarréico, contra } \\
\text { hemorragias }\end{array}$ & Liana & Cultivado & $\mathrm{NC}$ \\
\hline \multicolumn{8}{|l|}{ Scrophulariaceae } \\
\hline $\begin{array}{l}\text { Buddleja stachyoides } \\
\text { Cham. \& Schltdl. }\end{array}$ & $\begin{array}{c}\text { barbasco, babaço, } \\
\text { barbaço, calção-de- } \\
\text { velho }\end{array}$ & Folha e raiz & $\begin{array}{l}\text { Decocto ou } \\
\text { infuso }\end{array}$ & $\begin{array}{l}\text { Diurético, antigripal, } \\
\text { para afecções das vias } \\
\text { respiratórias, antidiarréico, } \\
\text { anti-inflamatório, resolutivo } \\
\text { em furúnculos, anti- } \\
\text { hemorroidal e afecções da } \\
\text { pele }\end{array}$ & Erva & Ruderal & 10186 \\
\hline \multicolumn{8}{|l|}{ Siparunaceae } \\
\hline $\begin{array}{l}\text { Siparuna brasiliensis } \\
\text { (Spreng.) A.DC. }\end{array}$ & cidra, negamina & Folha & Decocto & $\begin{array}{l}\text { Broncodilatador, béquico, } \\
\text { emenagogo }\end{array}$ & Arbusto & Floresta & 9423 \\
\hline \multicolumn{8}{|l|}{ Smilacaceae } \\
\hline Smilax sp. & japicanga & Raiz & Decocto & Antissifilítico & Liana & Floresta & 4150 \\
\hline \multicolumn{8}{|l|}{ Solanaceae } \\
\hline $\begin{array}{l}\text { Acnistus arborescens (L.) } \\
\text { Schltdl. }\end{array}$ & mariana & Folha & $\begin{array}{l}\text { Infuso ou } \\
\text { macerado }\end{array}$ & $\begin{array}{l}\text { Hemolítico, para afecções } \\
\text { hepáticas, antidiarréico }\end{array}$ & Arbusto & $\begin{array}{l}\text { Campo } \\
\text { rupestre }\end{array}$ & 16365 \\
\hline $\begin{array}{l}\text { Brugmansia suaveolens } \\
\text { (Willd.) Bercht. \& J.Presl }\end{array}$ & lírio, trombeta & Folha & Cigarro & Antiasmático & Arbusto & Cultivado & 9944 \\
\hline
\end{tabular}


TABELA 2. Espécies identificadas como medicinais em levantamento etnobotânico em área urbana no município de Ouro Preto, Minas Gerais, Brasil, 1998-2000. (V = voucher, número de registro no Herbário OUPR, NC = não coletado)

...continuação

\begin{tabular}{|c|c|c|c|c|c|c|c|}
\hline Cestrum nocturnum $\mathrm{L}$. & dama-da-noite & Caule & Infuso & Analgésico & Arbusto & Cultivado & 26516 \\
\hline $\begin{array}{l}\text { Nicotiana alata Link \& } \\
\text { Otto }\end{array}$ & fumo-bravo & Folha e raiz & Decocto & Para afecções intestinais & Erva & $\begin{array}{l}\text { Campo } \\
\text { rupestre }\end{array}$ & 4491 \\
\hline \multirow[t]{2}{*}{ Nicotiana tabacum L. } & fumo & Folha & $\begin{array}{l}\text { Emplasto } \\
\text { (com azeite de } \\
\text { mamona) }\end{array}$ & $\begin{array}{l}\text { Resolutivo em furúnculos } \\
\text { (uso tópico) }\end{array}$ & Erva & Cultivado & 9946 \\
\hline & & & Decocto & $\begin{array}{l}\text { Bochechos contra } \\
\text { odontalgias }\end{array}$ & & & \\
\hline $\begin{array}{l}\text { Solanum } \\
\text { alternatopinnatum Steud. }\end{array}$ & jequeri & Folha & $\begin{array}{l}\text { Decocto ou } \\
\text { infuso }\end{array}$ & $\begin{array}{l}\text { Anti-inflamatório para } \\
\text { afecções da garganta } \\
\text { (amigdalites, laringites e } \\
\text { faringites), para problemas } \\
\text { cardiovasculares }\end{array}$ & Liana & Floresta & 5508 \\
\hline Solanum americanum Mill. & $\begin{array}{l}\text { erva-moura, maria- } \\
\text { preta }\end{array}$ & Folha e fruto & Decocto & Diurético e calmante & Subarbusto & Ruderal & 22239 \\
\hline Solanum cernuum Vell. & $\begin{array}{c}\text { panaceia, braço- } \\
\text { de-preguiça, barba- } \\
\text { de-onça, barba-de- } \\
\text { bode, costa-branca }\end{array}$ & Folha & Decocto & $\begin{array}{l}\text { Para afecções renais } \\
\text { e urinárias, diurético, } \\
\text { hipotensor, contra artrite, } \\
\text { reumatismo, hidropisia, } \\
\text { anti-inflamatório, depurativo, } \\
\text { vermífugo, analgésico em } \\
\text { odontalgias, contra excesso } \\
\text { de ácido úrico, para reduzir } \\
\text { manchas na pele causadas } \\
\text { por mau funcionamento do } \\
\text { fígado, para o tratamento da } \\
\text { caxumba }\end{array}$ & Arbusto & Floresta & 2188 \\
\hline $\begin{array}{l}\text { Solanum cladotrichum } \\
\text { Dunal }\end{array}$ & $\begin{array}{l}\text { erva-de-santa- } \\
\text { bárbara }\end{array}$ & Folha & Infuso & Eupéptico & Subarbusto & Floresta & 15204 \\
\hline $\begin{array}{l}\text { Solanum lycocarpum } \\
\text { A.St.-Hil. }\end{array}$ & lobeira, frutade-lobo & Fruto & $\begin{array}{l}\text { Macerado em } \\
\text { água }\end{array}$ & $\begin{array}{l}\text { Hipoglicemiante, contra } \\
\text { hepatite e icterícia }\end{array}$ & Arbusto & $\begin{array}{c}\text { Campo } \\
\text { rupestre }\end{array}$ & 8185 \\
\hline Solanum melongena L. & beringela & Fruto & $\begin{array}{l}\text { Decocto ou } \\
\text { macerado em } \\
\text { água }\end{array}$ & $\begin{array}{l}\text { Hipocolesterolêmico, para } \\
\text { redução de peso }\end{array}$ & Subarbusto & Cultivado & 8185 \\
\hline \multirow[t]{2}{*}{ Solanum paniculatum L. } & jurubeba & Fruto & Decocto & $\begin{array}{l}\text { Para afecções hepáticas, } \\
\text { eupéptico, colagogo e } \\
\text { colerético }\end{array}$ & Arbusto & $\begin{array}{l}\text { Campo } \\
\text { rupestre }\end{array}$ & 22117 \\
\hline & & Raiz & Alcoolatura & $\begin{array}{l}\text { Colagogo, colerético, } \\
\text { eupéptico }\end{array}$ & & & \\
\hline $\begin{array}{l}\text { Lycopersicum esculentum } \\
\text { Mill. }\end{array}$ & tomate & Folha & Decocto & $\begin{array}{l}\text { Analgésico em odontalgias } \\
\text { (bochechos) }\end{array}$ & Subarbusto & Cultivado & 26474 \\
\hline \multicolumn{8}{|l|}{ Symplocaceae } \\
\hline $\begin{array}{l}\text { Symplocos celastrinea } \\
\text { Mart. }\end{array}$ & congonha & Folha & Decocto & $\begin{array}{l}\text { Para afecções renais, } \\
\text { diurético, calmante }\end{array}$ & Arbusto & Floresta & 22109 \\
\hline \multicolumn{8}{|l|}{ Theaceae } \\
\hline $\begin{array}{l}\text { Camellia sinensis (L.) } \\
\text { Kuntze }\end{array}$ & chá-preto & Folha & Infuso & $\begin{array}{l}\text { Antigripal, hipotensor, } \\
\text { estimulante, eupéptico }\end{array}$ & Arbusto & Cultivado & 1364 \\
\hline \multicolumn{8}{|l|}{ Tropaeolaceae } \\
\hline \multirow[t]{2}{*}{ Tropaeolum majus L. } & $\begin{array}{l}\text { chagas, chaguinha, } \\
\text { capuchinha, cuculiá }\end{array}$ & Folha & $\begin{array}{l}\text { Macerado ou } \\
\text { infuso com leite }\end{array}$ & $\begin{array}{l}\text { Estomáquico, para afecções } \\
\text { da pele, furunculose e acne }\end{array}$ & Erva & Cultivado & 7743 \\
\hline & & Flor & In natura & Para amigdalite & & & \\
\hline \multicolumn{8}{|l|}{ Urticaceae } \\
\hline $\begin{array}{l}\text { Cecropia pachystachya } \\
\text { Trécul }\end{array}$ & embaúba & Folha seca & Decocto & $\begin{array}{l}\text { Hipotensor, contra } \\
\text { taquicardia }\end{array}$ & Árvore & Floresta & 7426 \\
\hline Parietaria officinalis $\mathrm{L}$. & parietária & Folha & Decocto & $\begin{array}{l}\text { Para artrites, expectorante, } \\
\text { anti-inflamatório }\end{array}$ & Erva & Ruderal & 4037 \\
\hline $\begin{array}{l}\text { Urera baccifera (L.) } \\
\text { Gaudich. ex Wedd. }\end{array}$ & cansanção & Folha & Macerado & $\begin{array}{l}\text { Anti-inflamatório, cicatrizante } \\
\text { para feridas, hemostático } \\
\text { (uso tópico) }\end{array}$ & Arbusto & Floresta & 1362 \\
\hline
\end{tabular}


TABELA 2. Espécies identificadas como medicinais em levantamento etnobotânico em área urbana no município de Ouro Preto, Minas Gerais, Brasil, 1998-2000. (V = voucher, número de registro no Herbário OUPR, NC = não coletado)

...continuação

\begin{tabular}{|c|c|c|c|c|c|c|c|}
\hline Velloziaceae & & & & & & & \\
\hline $\begin{array}{l}\text { Vellozia compacta Mart. } \\
\text { ex Schult. \& Schult.f. }\end{array}$ & canela-de-ema & Parte aérea & $\begin{array}{l}\text { Infuso ou } \\
\text { Alcoolatura ou } \\
\text { decocto }\end{array}$ & $\begin{array}{l}\text { Contra dores musculares, } \\
\text { para contusões, } \\
\text { antirreumático, em fraturas } \\
\text { ósseas (uso tópico) }\end{array}$ & Erva & $\begin{array}{l}\text { Campo } \\
\text { rupestre }\end{array}$ & 1382 \\
\hline \multicolumn{8}{|l|}{ Verbenaceae } \\
\hline Lantana camara L & $\begin{array}{l}\text { camará, camará- } \\
\text { vermelho, cambará }\end{array}$ & Flor & Decocto & Antigripal & Subarbusto & $\begin{array}{l}\text { Campo } \\
\text { rupestre }\end{array}$ & 22082 \\
\hline Lantana fucata Lindl. & cambará-roxo & Folha e flor & Xarope & Béquico, expectorante & Subarbusto & $\begin{array}{l}\text { Campo } \\
\text { rupestre }\end{array}$ & 22240 \\
\hline Lippia alba (Mill.) N.E.Br. & $\begin{array}{c}\text { cidreira, erva- } \\
\text { cidreira, erva- } \\
\text { cidreira-de-árvore, } \\
\text { melissa, erva- } \\
\text { cidreira-de-folha, } \\
\text { erva-cidreira-de- } \\
\text { cipó }\end{array}$ & Folha & $\begin{array}{l}\text { Decocto ou } \\
\text { infuso }\end{array}$ & $\begin{array}{l}\text { Calmante, para gastrite, } \\
\text { antigripal, béquico, } \\
\text { hipotensor, antiespasmódico, } \\
\text { anticefaléico }\end{array}$ & Subarbusto & Cultivado & 7750 \\
\hline $\begin{array}{l}\text { Stachytarpheta } \\
\text { cayennensis (Rich.) Vahl }\end{array}$ & $\begin{array}{l}\text { homem-sem- } \\
\text { dinheiro, gervão, } \\
\text { jurubão, jurubom }\end{array}$ & Folha e raiz & Infuso & $\begin{array}{l}\text { Antigripal, para dores } \\
\text { musculares e torcicolo, } \\
\text { para distúrbios renais, } \\
\text { diurético, contra reumatismo, } \\
\text { amigdalite }\end{array}$ & Subarbusto & $\begin{array}{l}\text { Campo } \\
\text { rupestre }\end{array}$ & 16343 \\
\hline $\begin{array}{l}\text { Stachytarpheta glabra } \\
\text { Cham. }\end{array}$ & gervão, jurubão & Folha e raiz & Infuso & $\begin{array}{l}\text { Antigripal, para dores } \\
\text { musculares, reumatismo } \\
\text { e torcicolo, para distúrbios } \\
\text { renais, diurético }\end{array}$ & Subarbusto & $\begin{array}{l}\text { Campo } \\
\text { rupestre }\end{array}$ & 6814 \\
\hline \multicolumn{8}{|l|}{ Violaceae } \\
\hline Anchietea exalata Eichler & cipó-suma & Raiz & Decocto & Depurativo & Liana & Floresta & 9573 \\
\hline $\begin{array}{l}\text { Anchietea pyrifolia (Mart.) } \\
\text { G.Don }\end{array}$ & suma-branca & Raiz & Decocto & Depurativo, antissifilítico & Liana & Floresta & 8248 \\
\hline Viola odorata L. & violeta & Flor e folha & $\begin{array}{l}\text { Decocto ou } \\
\text { infuso }\end{array}$ & $\begin{array}{l}\text { Antigripal, antitérmico, } \\
\text { antiasmático }\end{array}$ & Erva & Cultivado & 6386 \\
\hline Viola tricolor $\mathrm{L}$. & amor-perfeito & Folha e flor & Infuso & $\begin{array}{l}\text { Depurativo, expectorante, } \\
\text { para afecções cutâneas, } \\
\text { contra cálculos biliares, no } \\
\text { tratamento de eczemas, } \\
\text { impetigo, herpes e } \\
\text { manifestações escrofulosas. }\end{array}$ & Erva & Cultivado & 7913 \\
\hline \multicolumn{8}{|l|}{ Vitaceae } \\
\hline $\begin{array}{l}\text { Cissus subrhomboidea } \\
\text { (Baker) Planch. }\end{array}$ & uva-do-mato & Folha & Decocto & $\begin{array}{l}\text { Para afecções renais e } \\
\text { uterinas }\end{array}$ & Liana & Cultivado & 1952 \\
\hline $\begin{array}{l}\text { Cissus verticillata (L.) } \\
\text { Nicolson \& C.E.Jarvis }\end{array}$ & insulina & Folha & $\begin{array}{l}\text { Decocto ou } \\
\text { infuso }\end{array}$ & Hipoglicemiante & Liana & Cultivado & 9092 \\
\hline Vitis vinifera $\mathrm{L}$. & uva & Fruto & Suco & Tônico, antianêmico & Liana & Cultivado & 7905 \\
\hline \multicolumn{8}{|l|}{ Winteraceae } \\
\hline Drimys brasiliensis Miers & casca-d'anta & Cascas e folha & $\begin{array}{l}\text { Decocto ou } \\
\text { alcoolatura }\end{array}$ & Antidiarréico, febrífugo & Arbusto & Floresta & 6798 \\
\hline \multicolumn{8}{|l|}{ Xanthorrhoeaceae } \\
\hline Aloe vera (L.) Burm.f. & babosa & Folha & $\begin{array}{l}\text { Macerado } \\
\text { ou infuso, } \\
\text { macerado com } \\
\text { cachaça e mel }\end{array}$ & $\begin{array}{l}\text { Para hidratação e } \\
\text { fortalecimento capilar, } \\
\text { anticaspa e queimaduras } \\
\text { (uso tópico), para } \\
\text { emagrecer, anti-inflamatório, } \\
\text { anticancerígeno }\end{array}$ & Erva & Cultivado & 7057 \\
\hline \multicolumn{8}{|l|}{ Xyridaceae } \\
\hline Xyris trachyphylla Mart. & botão-de-ouro & Planta toda & Decocto & $\begin{array}{l}\text { Para afecções da pele, } \\
\text { emético }\end{array}$ & Erva & $\begin{array}{l}\text { Campo } \\
\text { rupestre }\end{array}$ & 17456 \\
\hline
\end{tabular}


TABELA 2. Espécies identificadas como medicinais em levantamento etnobotânico em área urbana no município de Ouro Preto, Minas Gerais, Brasil, 1998-2000. (V = voucher, número de registro no Herbário OUPR, NC = não coletado)

...continuação

\begin{tabular}{|c|c|c|c|c|c|c|c|}
\hline \multicolumn{8}{|l|}{ Zingiberaceae } \\
\hline $\begin{array}{l}\text { Alpinia zerumbet (Pers.) } \\
\text { B.L.Burtt \& R.M.Sm. }\end{array}$ & pacová, baldâneo & Folha e raiz & Decocto & $\begin{array}{l}\text { Para combater o excesso } \\
\text { de ácido úrico, contra } \\
\text { hidropisias, anti-inflamatório, } \\
\text { para distúrbios renais, } \\
\text { diurético, antirreumático }\end{array}$ & Erva & Cultivado & 8299 \\
\hline Curcuma longa L. & $\begin{array}{l}\text { açafrão, açafrão-da- } \\
\text { terra, cúrcuma }\end{array}$ & Rizoma & $\begin{array}{l}\text { Macerado em } \\
\text { água }\end{array}$ & $\begin{array}{l}\text { Para o tratamento } \\
\text { de eczemas, } \\
\text { hipocolesterolêmico }\end{array}$ & Erva & Cultivado & 26517 \\
\hline Zingiber officinale Roscoe & gengibre & Rizoma & Xarope & $\begin{array}{l}\text { Antigripal, béquico, para o } \\
\text { tratamento de bronquite, } \\
\text { antigripal, para afecções } \\
\text { da garganta e das cordas } \\
\text { vocais e rouquidão }\end{array}$ & Erva & Cultivado & NC \\
\hline
\end{tabular}

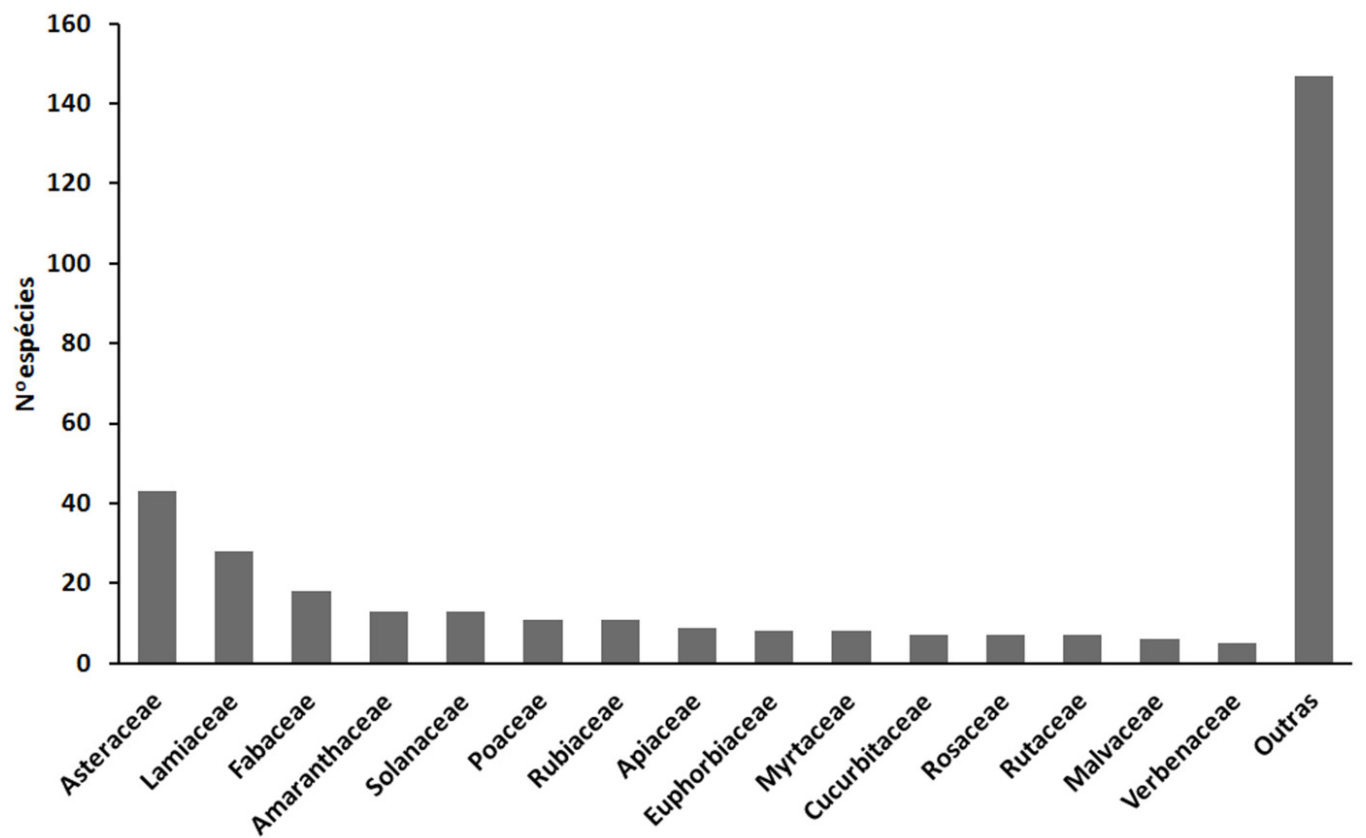

FIGURA 2. Famílias com maior riqueza de espécies medicinais em levantamento realizado na zona urbana do município de Ouro Preto, MG, 1998-2000.

As espécies mais citadas foram: hortelã (Mentha villosa), levante (M. longifolia) macelinha (Chamaemelum nobile), boldo (Plectranthus barbatus), funcho (Foeniculum vulgare), bálsamo (Cotyledon orbiculata), capim-cidreira (Cymbopogon citratus), alecrim (Rosmarinus officinalis), poejo (Mentha pulegium), transagem (Plantago major), manjericão (Ocimum basilicum), melissa (Melissa officinalis), losna (Artemisia absinthium), lavadeira (Leonurus japonicus), quebra-pedras (Phyllanthus niruri), arnica (Lychnophora ericoides), arruda (Ruta graveolens), cidreira (Lippia alba), saião (Bryophyllum pinnatum), milefólio (Achillea millefolium) e sálvia (Salvia officinalis). A frequência relativa de citação dessas espécies perfizeram $60 \%$ do valor total (Figura 3).

Dentre as espécies identificadas, $40 \%$ são exóticas, sobressaindo as de origem europeia, como a macelinha (Chamaemelum nobile), camomila (Matricaria chamomilla), melissa (Melissa officinalis) e as Mentha spp. Algumas espécies que não são nativas da região são adquiridas em farmácias ou no mercado, na forma de produto fitoterápico, aromático, ou alimentício, como por exemplo, o guaraná (Paulinia cupana), ruibarbo (Rheum palmatum), espinheira-santa (Maytenus ilicifolia), entre outras. Devido a este fato, elas não foram coletadas para constituir material testemunho herborizado.

As principais moléstias tratadas com 


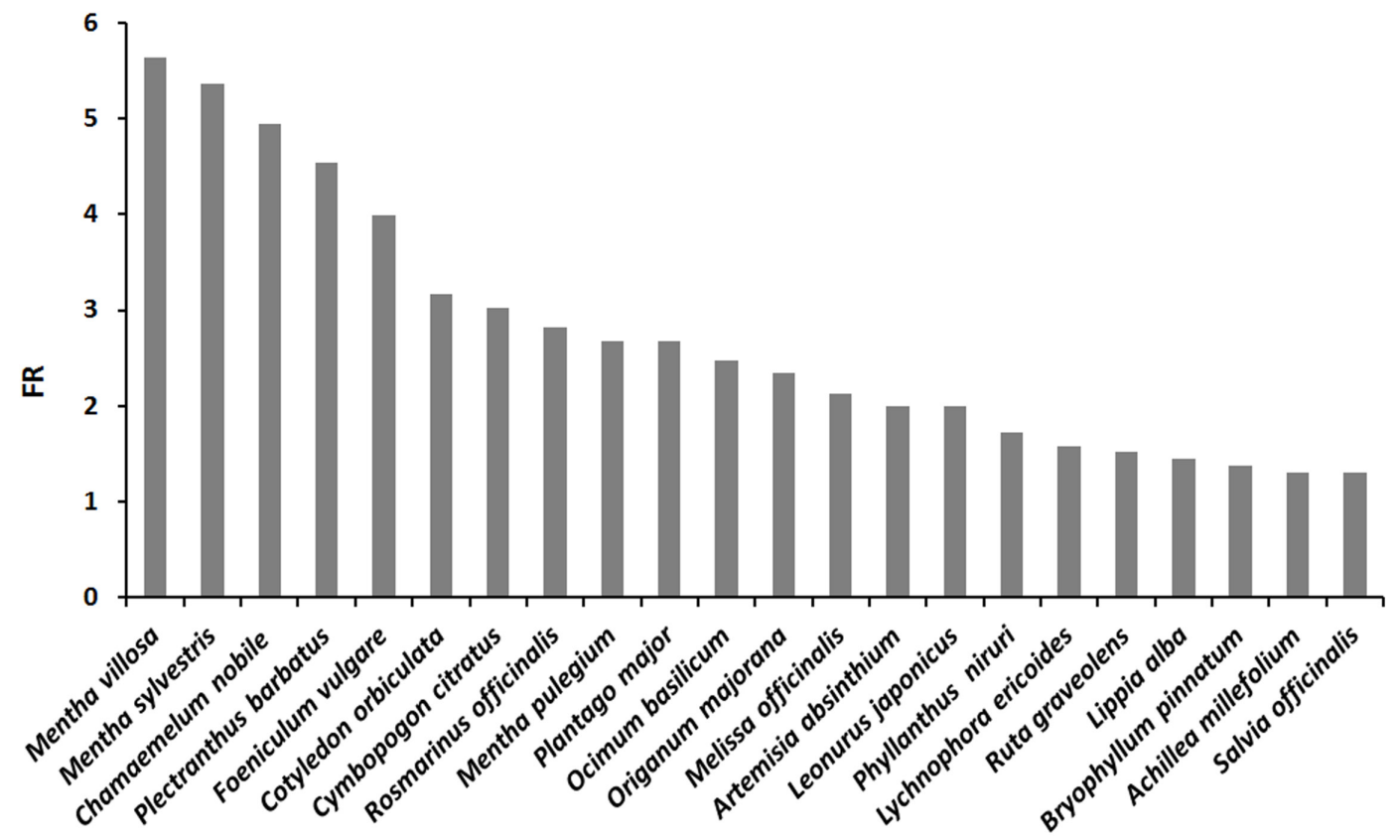

FIGURA 3. Espécies medicinais com maior valor de frequência relativa (FR) de citações, em um levantamento realizado na zona urbana do município de Ouro Preto, MG, 1998-2000.

plantas foram: diarreia, insônia, doenças do trato respiratório, hepáticas e renais (Tabela 2). O uso místico de espécies, comuns em rituais africanos, embora presente na cultura popular do município, ocorreu em pequena escala. Dentre essas se encontram a guiné (Petiveria alliacea), a arruda (Ruta graveolens), o pinhão (Jatropha curcas), o comigo-ninguém-pode (Dieffenbachia seguine) e a espada-de-são-jorge (Sansevieria trifasciata) citadas principalmente contra "mau-olhado". É interessante notar que dentre essas espécies citadas, apenas a espada-de-são-jorge é de origem africana, sendo o uso das outras espécies incorporado aos saberes tradicionais desses povos. Outras espécies africanas são usadas como fitoterápicos, com largo uso popular, como o boldo (Plectranthus barbatus) e o capim-cidreira (Cymbopogon citratus). Espécies exóticas cultivadas predominam na sede urbana de Ouro Preto e nos distritos de Cachoeira do Campo e Amarantina, onde as atividades agrícolas são mais expressivas. No entanto, $60 \%$ das espécies citadas são nativas, muitas delas carecendo de referências farmacológicas e fitoquímicas. Dentre estas, podemos citar a Vellozia compacta, a conhecida canela-de-ema, algumas espécies de llex, chamadas de congonha e as arnicas pertencentes a várias espécies do gênero Lychnophora. Vários estudos têm comprovado as propriedades medicinais dessas espécies. Por exemplo, a ação analgésica e antiinflamatória de diversas espécies de Lychnophora são relatadas por Guzzo et al. (2008) e Borsato et al.
(2000). No entanto, estudos ecológicos de espécies de Lychnophora são necessários, uma vez que nos campos rupestres onde ocorrem, encontram-se em populações reduzidas pela coleta predatória e destruição de seus habitats. Na região de Ouro Preto, chegam quase ao desaparecimento em diversas áreas como na serra de Lavras Novas e do Itacolomi. Várias espécies deste gênero figuram na lista das espécies ameaçadas de extinção de Minas Gerais (COPAM, 1997) e do Brasil (MMA, 2008), como por exemplo, Lychnophora brunioides e L. ericoides.

Muitas outras espécies presentes neste levantamento são também citadas nessas listas de espécies ameaçadas, como o pequi (Caryocar brasiliense), cipó-azougue (Melothrianthus smilacifolius), congonha (llex affinis), ipeca (Carapichea ipecacuanha), espinheira-santa (Maytenus ilicifolia), pacari (Lafoensia pacari), cipó-prata (Banisteriopsis harleyi), barbatimão (Stryphnodendron adstringens), carne-de-vaca (Roupala brasiliensis), jenipapo (Genipa americana) e azeitona-do-mato (Vitex polygama).

Diversas espécies diferentes recebem o mesmo nome popular, algumas delas apresentando constituintes químicos ou propriedades bastante distintas. Entre elas, são citadas como exemplos: Acanthospermum australe (Asteraceae) e Boerhavia diffusa (Nyctaginaceae) (Apu et al., 2012; Chaudhary \& Dantu, 2011; Martins et al., 2006), ambas denominadas por erva-tostão. Diferentes 
espécies utilizadas popularmente para problemas hepáticos (Plectranthus barbatus, $P$. neochilus e Gymnanthemum amygdalinum) são chamadas de boldo. E ainda, semelhanças morfológicas, como bordos foliares espinescentes, também levam à denominação de diferentes espécies por "espinheira-santa", como Maytenus ilicifolia e Sorocea bonplandii, que apesar de possuírem diferentes constituintes químicos, ambas apresentam propriedades antiúlcera gástrica. No entanto, a falta de estudos que assegurem a ausência de toxicidade de $S$. bonplandii reverte em risco para as pessoas que inadvertidamente a consomem (Santos-Oliveira, 2009). Melissa officinalis, Cymbopogon citratus e Lippia alba são conhecidas como "cidreira". Embora apenas Melissa officinalis seja reconhecida como a legítima "cidreira", pelas farmacopeias americana e europeia, essas três espécies tem revelado algumas substâncias químicas em comum (Ferro et al., 1996) e, consequentemente, algumas propriedades medicinais semelhantes (Gazola et al., 2004).

Foi constatado também o uso de várias plantas tóxicas, por exemplo, o confrei (Symphytum officinale) e o mentrasto (Ageratum conyzoides), que a despeito da presença de alcaloides pirrolizidínicos (Wiedenfeld \& Roder, 1991) com ação cancerígena, são usados em formulações para uso interno. Nesse sentido, fazem-se necessários trabalhos de extensão junto à população, esclarecendo sobre alguns aspectos da utilização de fitoterápicos.

Pelas análises estatísticas, notou-se que o nível de conhecimento sobre plantas medicinais pela população de Ouro Preto, em termos de riqueza de espécies citadas, independe do nível econômico, sexo, grau de escolaridade e do distrito de moradia. Porém, os moradores dos distritos, assim como os da sede, residindo em bairros próximos às áreas de vegetação natural (como as comunidades vizinhas a unidades de conservação do Morro de São João, Morro de Santana, Morro de São Sebastião, Pocinho e Botafogo), conhecem maior número de espécies nativas.

A idade mostrou-se como um fator significativo no saber popular das plantas medicinais (Figura 4), onde a classe de menor faixa etária apresentou a menor média de plantas citadas, diferindo da média dos indivíduos mais idosos amostrados, acima de 50 anos $(p<0.05)$. Embora os resultados sugiram uma perda de conhecimento tradicional sobre plantas medicinais das novas gerações, esta afirmação precisa ser vista com cautela. De acordo com Toledo \& Barrera-Bassols (2010), Voeks \& Leoni (2004) e Hanazaki et al. (2000), este fato pode também ser devido ao maior o tempo de aquisição do conhecimento tradicional das pessoas mais idosas.

Outro fator decisivo sobre o conhecimento de plantas medicinais é a forma de aprendizado. Pessoas que adquiriram o conhecimento sobre plantas medicinais por tradição familiar, livros ou combinação dessas formas, ou ainda através de outras pessoas, conhecem um maior número de espécies (Figura 5). O número de espécies citadas pelos entrevistados com essas formas de aquisição

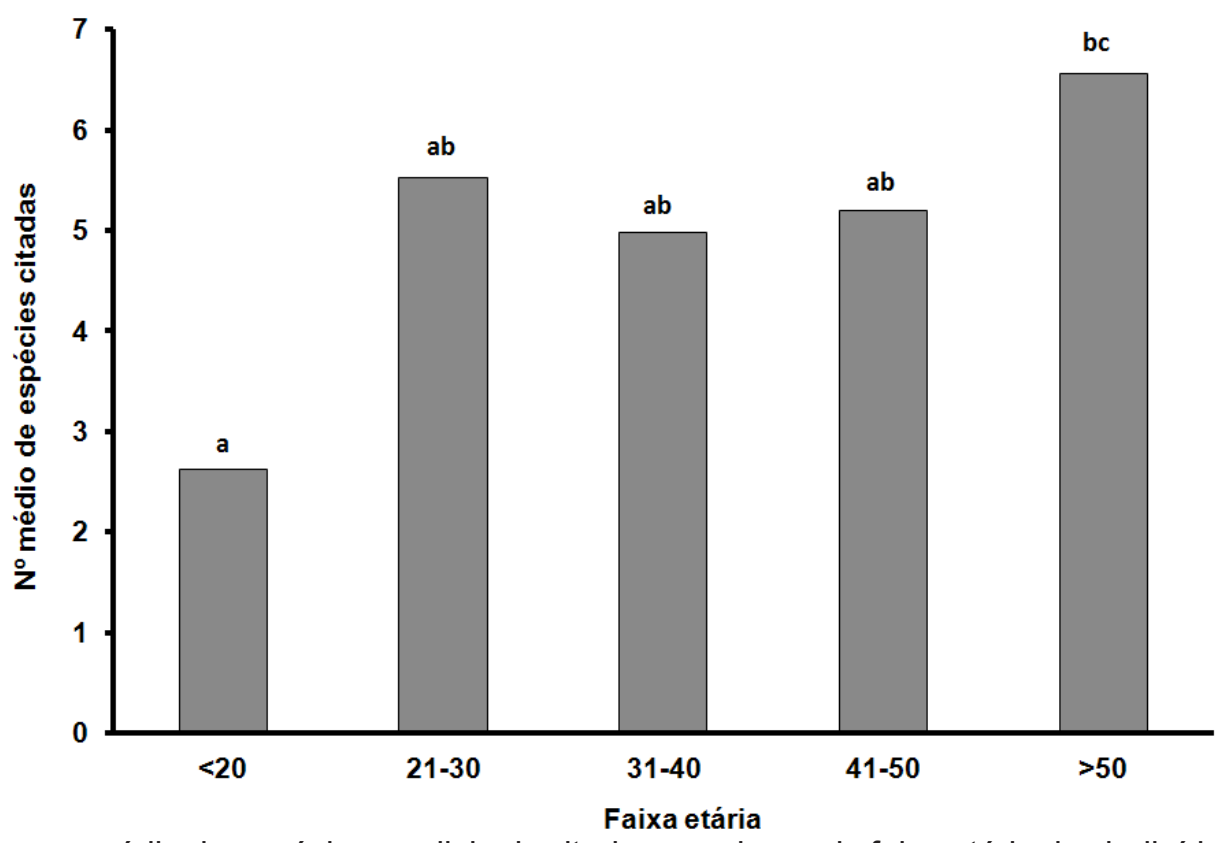

FIGURA 4. Número médio de espécies medicinais citadas por classe de faixa etária dos indivíduos entrevistados na zona urbana de Ouro Preto, MG, 1998-2000. Médias seguidas pela mesma letra não diferem estatisticamente entre si pelo teste de Tukey a $5 \%$ de probabilidade. 


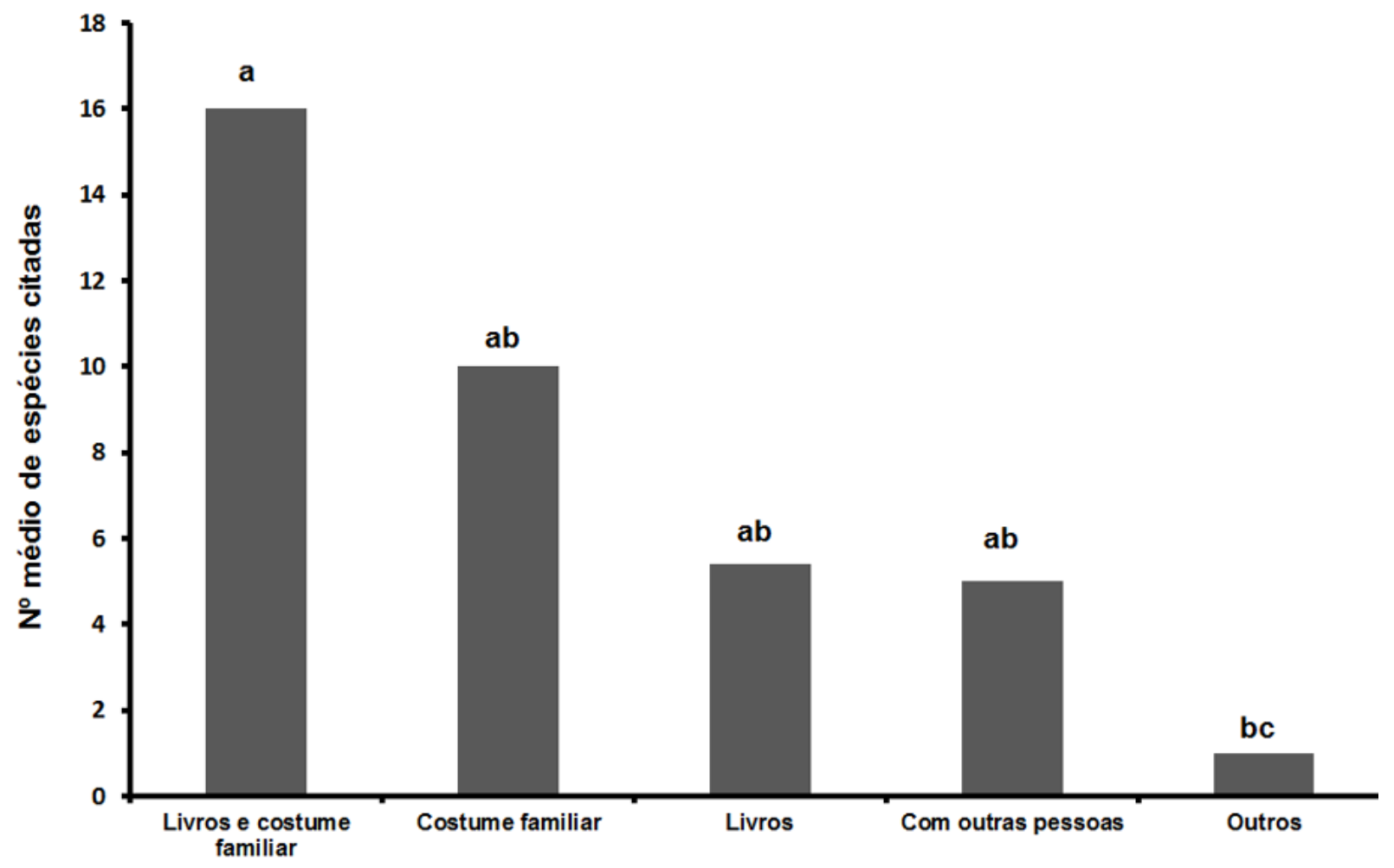

FIGURA 5. Número médio de espécies medicinais citadas por pessoas na zona urbana de Ouro Preto, MG, 1998-2000, com as diferentes formas de aquisição do conhecimento. Médias seguidas pela mesma letra não diferem estatisticamente entre si, pelo teste de Tukey ao nível de $5 \%$ de probabilidade.

de conhecimento não diferiram estatisticamente entre si quanto ao número de espécies citadas. No entanto, aqueles que adquiriram o conhecimento sobre plantas medicinais por outras maneiras, como: revistas, jornais, televisão, rádio ou internet, conhecem menos espécies $(p<0,05)$

Os resultados obtidos poderão subsidiar a bioprospecção de novos fármacos, assim como nortear futuras ações extensionistas no município na área ambiental e da saúde. O conhecimento sobre o uso tradicional dos recursos tem se revelado como uma ferramenta para valorização dos bens naturais e estímulo a preservação ambiental, inclusive propiciando a elaboração de estratégias conservacionistas para o manejo e conservação das espécies envolvendo a participação efetiva da população local (Diegues, 2000). As plantas medicinais, devido a sua relação direta com a saúde e qualidade de vida, tornam-se argumentos fortes para criar nas comunidades uma compreensão da importância de se conservar os recursos naturais, pois, através delas adquire-se a consciência do valor das plantas e da preservação ambiental. Além disso, a valorização do uso das plantas medicinais se enquadra nos propósitos de Unidade de Conservação de uso sustentável, que cobrem grande parte das áreas do entorno da cidade de Ouro Preto. Deste modo, o resgate desse conhecimento tradicional contribui para a preservação do patrimônio cultural, natural e científico existentes nessa cidade, reconhecida como monumento mundial.

\section{AGRADECIMENTOS}

À FAPEMIG pelo apoio financeiro (CAG 2598/97) e à comunidade de Ouro Preto pela presteza em nos atender durante as entrevistas.

\section{REFERÊNCIAS}

ALBUQUERQUE, U.P.; HANAZAKI, N. As pesquisas etnodirigidas na descoberta de novos fármacos de interesse médico e farmacêutico: fragilidades e perspectivas. Revista Brasileira de Farmacognosia, v.16, p.678-89, 2006.

ALBUQUERQUE, U.P. et al. Métodos e técnicas para a coleta de dados etnobotânicos. In: Albuquerque, U.P. et al. (orgs.). Métodos e técnicas na pesquisa etnobotânica. 2. ed. Recife: COMUNIGRAF, 2008. p.41-72.

ALKMIN, F.F.; MARSHAK, S. Transamazonian orogeny in the southern São Francisco Craton Region, Minas Gerais, Brazil: evidence for paleoproterozoic collision and collapse in the Quadrilátero Ferrífero. Precambrian Research, v.90, p.29-58, 1998.

APG (Angiosperm Phylogeny Group). An update of the angiosperm phylogeny group classification for the orders and families of flowering plants: APG III. Botanical 
Journal of the Linnean Society, v.161, p.105-21, 2009.

APU, A.S. et al. Phytochemical screening and in vitro bioactivities of the extracts of aerial part of Boerhavia diffusa Linn. Asian Pacific Journal of Tropical Biomedicine, v.2, p. 673-8, 2012.

BALICK, M.J.; COX, P.A. Plants, people, and culture: The science of ethnobotany. New York: Scientific American Library, 1996. 228p.

BORSATO, M.L.C. et al. Analgesic activity of the lignans from Lychnophora ericoides. Phytochemistry, v.55, p.809-13, 2000.

CHAUDHARY, G.; DANTU, P.K. Morphological, phytochemical and pharmacological, studies on Boerhaavia diffusa L. Journal of Medicinal Plants Research, v.5, p.2125-30, 2011.

COPAM Lista das espécies ameaçadas de extinção da flora do Estado de Minas Gerais. Deliberação COPAM 085/97. Belo Horizonte: COPAM, 1997. 48p. Disponível em: <http://www.biodiversitas.org.br/florabr/MGespecies-ameacadas.pdf>. Acesso em: 18 fev. 2010.

DIEGUES, A.C. et al. Biodiversidade e Comunidades Tradicionais no Brasil. São Paulo: NUPAUB-USP, PROBIO-MMA, CNPq, 2000. 189p.

DI STASI, L.C. Plantas medicinais: Arte e ciência. Um guia de estudo interdisciplinar. São Paulo: UNESP, 1996, 230p.

FERRO, V.O. et al. Diagnose comparativa de três espécies vegetais comercializadas como "ervas cidreiras" Lippia alba (Mill) N.E.Br ex Britt \& Wilson. Cymbopogon citratus (D.C.) Stapf e Melissa officinalis L. Lecta, v.14, p.5363. 1996.

GAZOLA, R. et al. Lippia alba, Melissa officinalis and Cymbopogon citratus: effects of the aqueous extracts on the isolated hearts of rats. Pharmacological Research, v.50, p.477-80, 2004.

GUZZO, L.S. et al. Antinociceptive and anti-inflammatory activities of ethanolic extracts of Lychnophora species. Journal of Ethnopharmacology, v.116, p.120-4, 2008.

HANAZAKI, N. et al. Diversity of plant uses in two Caiçara communities from the Atlantic Forest coast, Brazil. Biodiversity and Conservation, v.9, p.597-615, 2000.

IBGE. Metodologia do Censo Demográfico de 1980. Rio de Janeiro: Fundação Instituto Brasileiro de Geografia e Estatística - IBGE. v.4, 1983. 478p.

IBGE. Censo Demográfico 2000 - Malha Municipal Digital do Brasil 1997. 2000. Disponível em: <http:// www.ibge.gov.br/cidadesat/default.php.>. Acesso em: 24 abr. 2002.

IBGE Censo Demográfico 2000 e 2010. 2010. Disponível em: <http://www.censo2010.ibge.gov.br/dados_ divulgados/index.php?uf=31>. Acesso em: 24 jul. 2012.
KAMINO, L.H.Y. et al. Relações florísticas entre as fitofisionomias florestais da Cadeia do Espinhaço, Brasil. Megadiversidade, v.4, n.1-2, p.39-49, 2007.

Lista de Espécies da Flora do Brasil. Jardim Botânico do Rio de Janeiro. 2013. Disponível em: <http:// floradobrasil.jbrj.gov.br/>. Acesso em: 27 abr. 2014

MAGURRAN, A.E. Measuring biological diversity. Oxford: Blackwell Science, 2004. 264p.

MARTINS, E.R. et al. Plantas medicinais. Viçosa: UFV Imprensa Universitária, 2003. 220p.

MARTINS, L.R.R. et al. Atribuição dos deslocamentos químicos dos átomos de $1 \mathrm{H}$ e $13 \mathrm{C}$ do acetato de acantoaustralida. Revista Brasileira de Farmacognosia, v.16, p.490-6, 2006.

MINITAB. Minitab for Windows. Versão 15. Statistical Software. USA State College, PA: Minitab, Inc. 2008.

MMA (Ministério do Meio Ambiente). Lista oficial das espécies da flora brasileira ameaçadas de extinção. Instrução Normativa Nº 6 de 23/09/2008. Disponível em: <http://portal.saude.gov.br/portal/arquivos/pdf/ MMA_IN_N_6.pdf >. Acesso em: 18 ago. 2012.

NIMER, E. Climatologia do Brasil. 2.ed. Rio de Janeiro: Fundação IBGE, 1989. 421p.

PILLA, M.A.C. et al. Obtenção e uso das plantas medicinais no distrito de Martim Francisco, município de Mogi-Mirim, SP, Brasil. Acta Botanica Brasilica v.20, p.789-802, 2006.

RIZZINI, C.T. Tratado de fitogeografia do Brasil. Rio de Janeiro: Âmbito Cultural, 1997. 374 p.

SANTOS-OLIVEIRA, R. et al. Revisão da Maytenus ilicifolia Mart. ex Reissek, Celastraceae. Contribuição ao estudo das propriedades farmacológicas. Revista Brasileira de Farmacognosia, v.19, p.650-9, 2009.

SIMÕES, C.M. et al. Farmacognosia - Da planta ao medicamento. 2.ed. Porto Alegre/ Florianópolis: Ed. UFRGS/Ed. UFSC, 2000. 821p.

THE PLANT LIST. The plant list: A working list of all plant species. Version 1.1. 2013. Disponível em: <http://www. theplantlist.org>. Acesso em: 28 mar. 2014

TOLEDO, V.M.; BARRERA-BASSOLS, N. A etnoecologia: uma ciência pós-normal que estuda as sabedorias tradicionais. In: Silva, V.A. et al. (org.). Etnobiologia e Etnoecologia: Pessoas \& Natureza na América Latina. v.1, Recife: NUPEEA. 2010. p.13-36.

VOEKS, R.A.; LEONY, A. Forgetting the forest: Assessing medicinal plant erosion in Eastern Brazil. Economic Botany, v.58, p.294-306, 2004.

WIEDENFELD, H.; RODER, E. Pyrrolizidine alkaloids from Ageratum conyzoides. Planta Medica, v.57, p.578-9, 1991.

ZAR J.H. Biostatistical analysis. 4.ed., New Jersey: Prentice Hall, 1999. 663p. 